\title{
Major ion chemistry of the Son River, India: Weathering processes, dissolved fluxes and water quality assessment
}

\author{
Chinmaya Maharana $^{1}$, Sandeep Kumar Gautam ${ }^{1}$, \\ Abhay Kumar Singh ${ }^{2}$ and Jayant K Tripathi, ${ }^{1, *}$ \\ ${ }^{1}$ School of Environmental Sciences, Jawaharlal Nehru University, New Delhi 110 067, India. \\ ${ }^{2}$ Central Institute of Mining and Fuel Research, Barwa Road, Dhanbad, Jharkhand 826 001, India. \\ ${ }^{*}$ Corresponding author.e-mail: jktrip@yahoo.com
}

River Son, draining diverse lithologies in the subtropical climate of the peninsular sub-basin of the Ganga basin, is one of the major tributaries of the Ganga River. The chemistry of major ions in the surface water of the Son River was studied in detail to determine various source(s) and processes controlling its water chemistry, seasonal and spatial variations in water chemistry, dissolved fluxes and chemical denudation rate (CDR). The study shows that $\mathrm{Ca}^{2+}, \mathrm{Mg}^{2+}$ and $\mathrm{HCO}_{3}^{-}$are major ionic species in the river water. Most of the measured parameters exhibit a relatively lower concentration in the post-monsoon as compared to pre-monsoon season. The water chemistry highlights the influence of continental weathering aided by secondary contributions from ground water, saline/alkaline soils and anthropogenic activities in the catchment. Results also reflect the dominance of carbonate weathering over silicate weathering in controlling water composition. The Son River delivers about 4.2 million tons of dissolved loads annually to the Ganga River, which accounts for $\sim 6 \%$ of the total annual load carried by the Ganga River to the Bay of Bengal. The average CDR of the Son River is 59.5 tons $\mathrm{km}^{-2} \mathrm{yr}^{-1}$, which is less than the reported 72 tons $\mathrm{km}^{-2} \mathrm{yr}^{-1}$ of the Ganga River and higher than the global average of 36 tons $\mathrm{km}^{-2} \mathrm{yr}^{-1}$. The water chemistry for the pre-monsoon and post-monsoon periods shows a strong seasonal control on solute flux and CDR values. The water chemistry indicates that the Son River water is good to excellent in quality for irrigation and also suitable for drinking purposes.

\section{Introduction}

Rivers are major dynamic water bodies responsible for most of the continental input to the world ocean and geochemical cycling of elements among continent-river-ocean systems. Rivers around the globe deliver about $90 \%$ of the continental weathering products along with anthropogenic inputs in the form of dissolved and particulate load into the world oceans (Garrels et al. 1975). A number of detailed geochemical studies are available on world rivers, dealing with the origin and fate of elements/pollutants, explaining various processes controlling river water chemistry on the basin scale. These studies also explain the exogenic cycling of elements in the continent-river-ocean systems (Livingstone 1963; Reeder et al. 1972; Carbonnel and Meybeck 1975; Subramanian 1979; $\mathrm{Hu}$ et al. 1982; Meybeck 1982, 2005; Stallard and Edmond 1983; Sarin et al. 1989; Bluth and

Keywords. Son River; Ganga basin; hydrogeochemistry; weathering; flux and denudation rates; water quality.

Supplementary data pertaining to this article are available on the Journal of Earth System Science Website at http://www.ias.ac.in/jess/aug2015/supp/Tripathi.pdf 
Kump 1994; Zhang et al. 1995; Galy and FranceLanord 1999; Hren et al. 2007; Li et al. 2009). Indian rivers have also been studied to understand (i) hydrological and environmental characteristics of river basins, (ii) influence of basin geology, tectonics, climate and anthropogenic activities on riverine chemistry and (iii) elemental fluxes from rivers to oceans (Subramanian 1979, 1983; Biksham and Subramanian 1988; Sarin et al. 1989; Chakrapani and Subramanian 1990; Ramanathan et al. 1994; Krishnaswami and Singh 1998; Ahmad et al. 1998; Singh and Hasnain 1999; Dalai et al. 2002; Singh et al. 2005; Sharma and Subramanian 2008; Jha et al. 2009; Rengarajan et al. 2009; Gupta et al. 2011).

In order to understand the dynamics of large river systems properly, it is essential to study the medium and small rivers present within their basins. For example, the Ganga River system has several medium to small-sized tributaries, and the water chemistry of tributaries significantly influences the composition of the Ganga River water (Sarin et al. 1989). Previous studies on the Ganga River system were mainly confined to the Himalayan catchments and north joining tributaries, whereas peninsular rivers joining from the south have received little attention. The Son River, a major tributary in the peninsular sub-basin of the Ganga River, has been studied for water chemistry and quality assessment for only a few locations (Subramanian 1984; Sarin et al. 1989; Rai et al. 2010; Rani et al. 2011). Sarin et al. (1989) reported the significant silicate weathering rather than carbonate weathering for the Son basin, whereas Rai et al. (2010) reported higher carbonate weathering rate than silicate weathering rate based on the water chemistry at Koelwar. No serious attempts have been made to study the weathering processes in the Son River on a basin scale. Therefore, in order to have better understanding, a detailed hydrogeochemical investigation of the Son River has been carried out to determine the major ion chemistry and their source(s), to understand the role of weathering and other geochemical processes (precipitation and dissolution of minerals/salts, redox processes, etc.) in controlling the water composition of the Son River in the peninsular sub-basin of the Ganga River. The geochemical data have also been used to assess the dissolved fluxes and chemical denudation rate of the Son River, its contribution to water chemistry of the Ganga River and suitability of its water for irrigation and drinking purposes.

\section{Study area}

The Son River basin is one of the major subbasins of the Ganga River basin (figure 1). Unlike the Himalayan-glacial-fed tributaries of the Ganga River, the rain-fed Son River is the principal peninsular tributary of the river Ganga. The Son River originates in the Amarkantak hills of Maikal range at an elevation of $1030 \mathrm{~m}$ in central India and traverses for about $784 \mathrm{~km}$, of which $500 \mathrm{~km}$ lies in the Madhya Pradesh, $82 \mathrm{~km}$ in Uttar Pradesh and remaining $202 \mathrm{~km}$ in Jharkhand and Bihar states of India. The total catchment area of the Son River is $71,259 \mathrm{~km}^{2}$ (Rao 1975). After its origin, it flows north-northwest through Madhya Pradesh, then it turns sharply eastward and encounters the southwest-northeast running Kaimur group of the

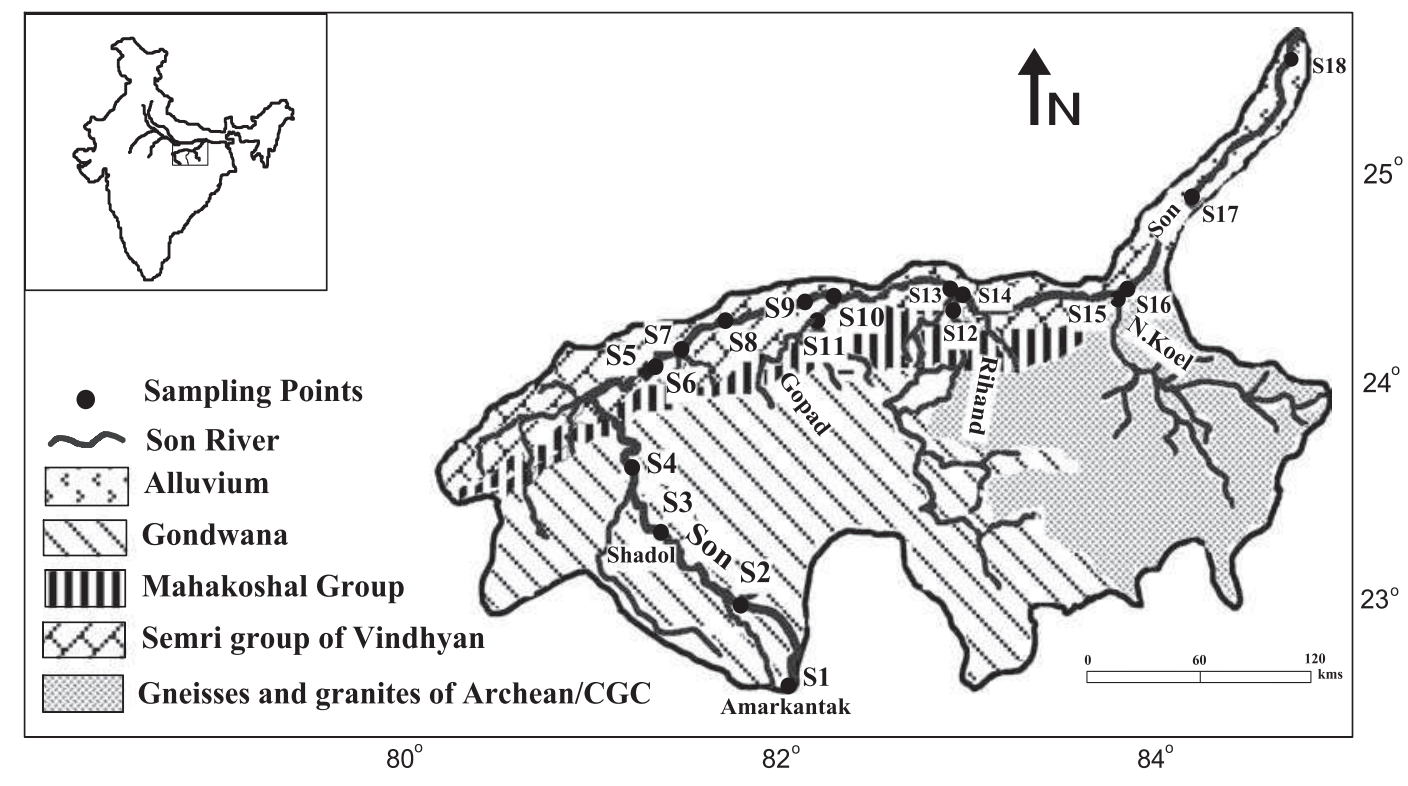

Figure 1. Geological map of Son River basin with sampling locations. 
Vindhyan Super Group. Then it flows in the eastnortheast direction, and parallels to the Kaimur range, through Uttar Pradesh, Jharkhand and Bihar states before joining the river Ganga near Patna city of Bihar.

From its origin to the mouth the Son River drains diverse lithological units of the peninsula. The major lithological units appear within the Son River basins are of the Gondwana and Vindhyan Super Groups, Mahakoshal Group, Chhotanagpur Granitic Complex and Quaternary Alluvium (figure 1). The Son River principally flows through sandstones and shales of the Gondwanas, sandstones, shales and carbonates of the Semri, sandstones, shale and minor carbonates of the Kaimur Groups of the Vindhyan Super Group, and the Quarternary Alluvium. Tributaries of the Son River, the Rihand, North Koel and Gopad, flow through the Gondwanas, Mahakoshal Group, Archean gneiss and Chhotanagpur Granitic Complex (Gneisses, granites) (Lakshmanan 1970; Ray et al. 2003; Ramakrishnan and Vaidyanadhan 2008). Major groups of soils of the Son basin are red yellow soil, red sandy soil and younger alluvial soil. The upper reaches of the Son River is forested while in lower reaches it consists of scrub and grasses. The Son basin experiences a subtropical climate having hot dry summer (MarchJune), monsoon rain (July-October) and winter (November-January) seasons.

\section{Sample collection and analytical methodology}

Thirty-five water samples at 18 locations (Supplementary data) on the Son River and its tributaries were collected during the pre-monsoon (May) and post-monsoon (November) seasons of the year 2010. Water samples collected from the mouth of the Son before meeting the Ganga at Koelwar during the pre-monsoon (April) and monsoon (August) seasons of the year 2013 were utilized for the estimation of flux and CDR. Water samples were collected in one litre narrow-mouth pre-washed polyethylene bottles from the main river channel, tributaries and reservoir (figure 1). One aliquot of the collected samples $(100 \mathrm{ml})$ were filtered on site using Millipore syringe filters $(0.45 \mu \mathrm{m})$ and acidified immediately by using supra pure $\mathrm{HNO}_{3}$ and kept carefully till analysis. Another aliquot of the samples $(500 \mathrm{ml})$ were filtered through $0.45 \mu \mathrm{m}$ Millipore membrane filters to separate suspended sediments and preserved at $4^{\circ} \mathrm{C}$ for further analysis. Water samples were analysed for $\mathrm{pH}$ and electrical conductivity (EC) using pH-EC meter. Total dissolved solid (TDS) was calculated by summation of all dissolved components.
Major cations $\left(\mathrm{Ca}^{2+}, \mathrm{Mg}^{2+}, \mathrm{Na}^{+}\right.$and $\left.\mathrm{K}^{+}\right)$in acidified samples and major anions $\left(\mathrm{F}^{-}, \mathrm{Cl}^{-}, \mathrm{HCO}_{3}^{-}\right.$, $\mathrm{SO}_{4}^{2-}-\mathrm{NO}_{3}^{-}$) and dissolved silica in nonacidified samples were analysed following standard analytical methods (APHA 1998). Concentration of bicarbonate was determined by acid titration method and $\mathrm{F}^{-}, \mathrm{Cl}^{-}, \mathrm{SO}_{4}^{2-}$ and $\mathrm{NO}_{3}^{-}$were analysed on an ion chromatograph (Dionex Dx-120) using anion (AS12A/AG12) columns coupled to an anion self-regenerating suppressor (ASRS) in recycle mode. Concentration of $\mathrm{Ca}^{2+}$ and $\mathrm{Mg}^{2+}$ were determined using ICP-AES (Ultima-2, JY Horiba). $\mathrm{Na}^{+}$and $\mathrm{K}^{+}$were measured by AAS (Varian, 280 FS) in flame mode. Dissolved silica concentration in water was measured by molybdosilicate method with the help of UV-VIS spectrophotometer. The analytical precision was maintained by running a known standard after every 10 samples. An overall precision was obtained below $10 \%$ for all the samples.

\section{Results and discussion}

\subsection{Major ion chemistry}

The major ion chemistry of the Son River, its tributaries and reservoir water for pre-monsoon and post-monsoon seasons are given in table 1(a). The table also shows $\mathrm{pH}$, EC, total hardness $(\mathrm{TH})$, sodium adsorption ratio (SAR), $\% \mathrm{Na}$ and residual sodium carbonate (RSC) values. Statistical analysis of the data shows that the total cations $\left(\mathrm{TZ}^{+}\right)$ and total anions $\left(\mathrm{TZ}^{-}\right)$are coupled by the relation $\mathrm{TZ}^{+}=0.908 \mathrm{TZ}^{-} \pm 32.4$ with a correlation coefficient $r^{2}=0.95$ for the analysed water samples. Like other Indian rivers, water samples in the Son River and its tributaries are alkaline in nature (Subramanian 1979). The water found to be slightly acidic at the origin (S-1), which may be due to high organic loading in the forested region. The measured average $\mathrm{pH}$ of the river water is slightly higher in the pre-monsoon (8.0) as compared to the post-monsoon season (7.5). The electrical conductivity (EC) varies between 83-1314 $\mu \mathrm{S} \mathrm{cm}{ }^{-1}$ in pre-monsoon and $68-551 \mu \mathrm{S} \mathrm{cm}^{-1}$ during post-monsoon seasons with average values of $292 \mu \mathrm{S} \mathrm{cm}-1$ and $252 \mu \mathrm{S} \mathrm{cm} \mathrm{cm}^{-1}$, respectively. The total dissolved solid (TDS) concentration varies between 78 and $797 \mathrm{mg} \mathrm{l}^{-1}$ (average $234 \mathrm{mg} \mathrm{l}^{-1}$ ) during the pre-monsoon and between 64 and 412 $\mathrm{mg} \mathrm{l}^{-1}$ (average $220 \mathrm{mg} \mathrm{l}^{-1}$ ) in the post-monsoon season.

Major anions in the Son River surface water account for $69 \%$ of the TDS. Bicarbonate is the most dominant ion in the analysed water samples, accounting for $58 \%$ of the total dissolved load. The concentration of $\mathrm{HCO}_{3}^{-}$varies from 688 to 


\begin{tabular}{|c|c|c|c|c|c|c|c|c|c|c|c|c|c|c|c|c|c|c|c|c|c|}
\hline Sl. no. & Samp. location & $\mathrm{pH}$ & $\mathrm{EC}$ & TDS & $\mathrm{F}$ & $\mathrm{Cl}$ & $\mathrm{HCO}_{3}$ & $\mathrm{SO}_{4}$ & $\mathrm{NO}_{3}$ & Silica & $\mathrm{Ca}$ & $\mathrm{Mg}$ & $\mathrm{Na}$ & K & $\mathrm{TH}$ & $\mathrm{PCO}_{2}$ & SIC & SID & SAR & $\mathrm{RSC}$ & $\% \mathrm{Na}$ \\
\hline $1 \mathrm{a}$ & Amarkantk & 6.0 & 83 & 78 & 16 & 56 & 688 & 7 & 89 & 219 & 220 & 99 & 113 & 5 & 32 & -1.34 & -2.82 & -5.57 & 0.20 & 0.06 & 15.7 \\
\hline $1 b$ & & 6.8 & 68 & 64 & 8 & 43 & 606 & 10 & 44 & 153 & 175 & 95 & 91 & 27 & 27 & -2.19 & -2.17 & -4.20 & 0.17 & 0.07 & 17.8 \\
\hline $2 \mathrm{a}$ & Annupur & 8.0 & 276 & 218 & 31 & 141 & 2016 & 91 & 9 & 455 & 719 & 247 & 635 & 79 & 97 & -2.88 & 0.16 & 0.26 & 0.65 & 0.09 & 27.0 \\
\hline $2 \mathrm{~b}$ & & 7.5 & 221 & 182 & 14 & 130 & 1704 & 127 & 4 & 262 & 666 & 247 & 405 & 90 & 91 & -2.45 & -0.45 & -0.92 & 0.42 & -0.13 & 21.3 \\
\hline $3 \mathrm{a}$ & Diapiper & 8.2 & 1314 & 797 & 25 & 6767 & 2950 & 820 & 8 & 372 & 3640 & 876 & 4167 & 312 & 452 & -2.91 & 1.23 & 2.25 & 1.96 & -6.08 & 33.1 \\
\hline $3 b$ & & 7.5 & 551 & 412 & 25 & 2279 & 2016 & 844 & 1 & 251 & 1312 & 498 & 1827 & 127 & 181 & -2.38 & -0.08 & -0.17 & 1.36 & -1.60 & 35.1 \\
\hline $4 \mathrm{a}$ & Jaisingnagar & 8.4 & 315 & 256 & 58 & 564 & 2065 & 260 & 8 & 498 & 699 & 436 & 544 & 64 & 114 & -3.26 & 0.56 & 1.32 & 0.51 & -0.20 & 21.1 \\
\hline $4 b$ & & 7.7 & 304 & 253 & 16 & 423 & 2344 & 157 & 1 & 340 & 856 & 411 & 539 & 80 & 127 & -2.51 & 0.00 & 0.09 & 0.48 & -0.20 & 19.7 \\
\hline $5 \mathrm{a}$ & Bansagar & 8.7 & 189 & 162 & 19 & 127 & 1655 & 60 & 3 & 219 & 581 & 247 & 270 & 44 & 83 & -3.66 & 0.69 & 1.40 & 0.29 & 0.01 & 15.9 \\
\hline $5 \mathrm{~b}$ & & 7.5 & 174 & 161 & 28 & 124 & 1639 & 54 & 21 & 234 & 551 & 218 & 222 & 77 & 77 & -2.47 & -0.55 & -1.09 & 0.25 & 0.09 & 16.1 \\
\hline $6 a$ & Khand & 8.2 & 222 & 184 & 19 & 135 & 1868 & 58 & 3 & 259 & 674 & 247 & 348 & 62 & 92 & -3.11 & 0.30 & 0.57 & 0.36 & 0.03 & 18.2 \\
\hline $6 \mathrm{~b}$ & & 7.5 & 185 & 170 & 14 & 119 & 1754 & 55 & 2 & 234 & 571 & 251 & 270 & 82 & 83 & -2.43 & -0.50 & -0.94 & 0.30 & 0.11 & 17.6 \\
\hline $7 \mathrm{a}$ & Rampurnaikin & 8.3 & 221 & 190 & 32 & 423 & 1786 & 9 & 5 & 400 & 479 & 263 & 426 & 97 & 74 & -3.23 & 0.23 & 0.62 & 0.49 & 0.31 & 26.0 \\
\hline $7 \mathrm{~b}$ & & 7.6 & 265 & 237 & 20 & 144 & 2589 & 42 & 14 & 261 & 761 & 399 & 452 & 68 & 116 & -2.37 & -0.11 & -0.08 & 0.42 & 0.27 & 18.3 \\
\hline $8 \mathrm{a}$ & Churhat & 8.2 & 249 & 186 & 52 & 282 & 1688 & 30 & 10 & 476 & 417 & 259 & 561 & 110 & 68 & -3.15 & 0.05 & 0.29 & 0.68 & 0.33 & 33.1 \\
\hline $8 \mathrm{~b}$ & & 7.8 & 222 & 196 & 14 & 105 & 2212 & 31 & 2 & 224 & 579 & 305 & 326 & 80 & 88 & -2.64 & -0.09 & -0.06 & 0.35 & 0.44 & 18.7 \\
\hline $9 \mathrm{a}$ & Dhehra & 8.2 & 249 & 193 & 39 & 141 & 2016 & 2 & 13 & 339 & 332 & 399 & 709 & 100 & 73 & -3.08 & 0.03 & 0.54 & 0.83 & 0.55 & 35.6 \\
\hline $9 b$ & & 7.7 & 239 & 214 & 15 & 102 & 2393 & 34 & 1 & 216 & 694 & 350 & 370 & 77 & 104 & -2.50 & -0.08 & -0.05 & 0.36 & 0.31 & 17.6 \\
\hline $10 \mathrm{a}$ & Khairpur & 8.3 & 324 & 287 & 30 & 423 & 2901 & 43 & 5 & 485 & 841 & 465 & 583 & 69 & 131 & -3.02 & 0.69 & 1.52 & 0.51 & 0.29 & 20.0 \\
\hline $11 \mathrm{a}$ & Gopad River & 7.9 & 151 & 134 & 29 & 155 & 1295 & 2 & 5 & 284 & 407 & 173 & 287 & 102 & 58 & -2.97 & -0.38 & -0.72 & 0.38 & 0.14 & 25.1 \\
\hline $11 b$ & & 7.4 & 137 & 129 & 12 & 60 & 1377 & 19 & 5 & 193 & 409 & 185 & 187 & 82 & 60 & -2.44 & -0.85 & -1.64 & 0.24 & 0.19 & 18.5 \\
\hline $12 \mathrm{a}$ & Rihand River & 7.5 & 143 & 120 & 57 & 141 & 967 & 104 & 8 & 266 & 347 & 152 & 387 & 59 & 50 & -2.70 & -0.98 & -1.90 & 0.55 & -0.03 & 30.9 \\
\hline $12 \mathrm{~b}$ & & 6.9 & 153 & 137 & 30 & 164 & 1246 & 95 & 34 & 183 & 374 & 173 & 431 & 82 & 55 & -1.98 & -1.43 & -2.79 & 0.58 & 0.16 & 31.9 \\
\hline $13 \mathrm{a}$ & Kargara & 8.4 & 278 & 275 & 21 & 843 & 2622 & 49 & 5 & 410 & 789 & 387 & 457 & 87 & 118 & -3.16 & 0.72 & 1.53 & 0.42 & 0.27 & 18.8 \\
\hline $13 \mathrm{~b}$ & & 7.6 & 259 & 234 & 15 & 89 & 2655 & 31 & 4 & 222 & 791 & 370 & 344 & 77 & 116 & -2.36 & -0.08 & -0.08 & 0.32 & 0.34 & 15.4 \\
\hline $14 \mathrm{a}$ & Chopan & 7.9 & 225 & 200 & 48 & 702 & 1737 & 93 & 6 & 282 & 551 & 272 & 452 & 74 & 82 & -2.84 & -0.12 & -0.14 & 0.50 & 0.09 & 24.2 \\
\hline $14 b$ & & 7.5 & 240 & 205 & 25 & 148 & 2212 & 76 & 6 & 219 & 616 & 280 & 400 & 78 & 90 & -2.34 & -0.37 & -0.67 & 0.42 & 0.41 & 21.1 \\
\hline $15 \mathrm{a}$ & Koel River & 8.4 & 302 & 277 & 65 & 561 & 2786 & 69 & 6 & 317 & 791 & 321 & 740 & 79 & 111 & -3.13 & 0.74 & 1.50 & 0.70 & 0.56 & 26.9 \\
\hline $15 b$ & & 7.9 & 385 & 365 & 28 & 235 & 3737 & 79 & 160 & 433 & 1080 & 518 & 1087 & 87 & 160 & -2.51 & 0.51 & 1.10 & 0.86 & 0.55 & 26.8 \\
\hline $16 \mathrm{a}$ & Japla & 7.9 & 247 & 230 & 6 & 559 & 2131 & 78 & 5 & 400 & 684 & 309 & 465 & 77 & 99 & -2.75 & 0.06 & 0.18 & 0.47 & 0.14 & 21.4 \\
\hline $16 b$ & & 7.6 & 258 & 229 & 19 & 161 & 2458 & 49 & 4 & 266 & 711 & 325 & 552 & 78 & 104 & -2.39 & -0.16 & -0.25 & 0.54 & 0.39 & 23.4 \\
\hline $17 \mathrm{a}$ & DOS & 8.0 & 246 & 220 & 39 & 561 & 2016 & 82 & 8 & 365 & 634 & 300 & 465 & 74 & 93 & -2.88 & 0.11 & 0.29 & 0.48 & 0.15 & 22.4 \\
\hline $17 \mathrm{~b}$ & & 7.7 & 351 & 310 & 14 & 399 & 3097 & 81 & 100 & 304 & 1008 & 457 & 831 & 83 & 147 & -2.39 & 0.20 & 0.45 & 0.69 & 0.17 & 23.8 \\
\hline $18 \mathrm{a}$ & Koelwar & 7.8 & 224 & 213 & 55 & 553 & 2016 & 74 & 3 & 259 & 581 & 342 & 509 & 67 & 92 & -2.68 & -0.13 & -0.09 & 0.53 & 0.17 & 23.8 \\
\hline $18 \mathrm{~b}$ & & 7.9 & 264 & 236 & 18 & 136 & 2589 & 56 & 14 & 251 & 724 & 342 & 470 & 73 & 107 & -2.67 & 0.17 & 0.43 & 0.45 & 0.46 & 20.3 \\
\hline
\end{tabular}

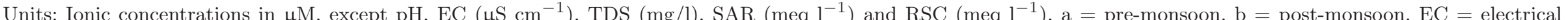

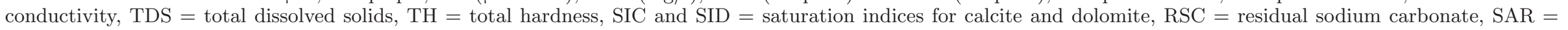
sodium adsorption ratio, DOS $=$ Dehri on Son. 
$2950 \mu \mathrm{M}$ in the pre-monsoon and $606-3737 \mu \mathrm{M}$ during the post-monsoon season. On an equivalent basis, $\mathrm{HCO}_{3}^{-}$alone accounts for $75 \%$ of the total anions ( $\left.\mathrm{TZ}^{-}\right)$, followed by $\mathrm{Cl}^{-}(16.6 \%), \mathrm{SO}_{4}^{2-}(5.7 \%)$, $\mathrm{F}^{-}(1.5 \%)$ and $\mathrm{NO}_{3}^{-}(0.8 \%)$. Chloride concentration varies from 56 to $6767 \mu \mathrm{M}$ with an average value of $730.6 \mu \mathrm{M}$ in pre-monsoon samples. The concentration of other measured anions in the premonsoon ranges between 2 and $820 \mu \mathrm{M}$ for $\mathrm{SO}_{4}^{2-}$, 3-89 $\mu \mathrm{M}$ for $\mathrm{NO}_{3}^{-}$and $6-65 \mu \mathrm{M}$ for $\mathrm{F}^{-}$. In the post-monsoon, $\mathrm{HCO}_{3}^{-}$accounts for $84 \%$ of the total anions, followed by $\mathrm{Cl}^{-}(8.2 \%), \mathrm{SO}_{4}^{2-}(6.5 \%), \mathrm{NO}_{3}^{-}$ $(1.0 \%)$ and $\mathrm{F}^{-}(0.8 \%)$ in the equivalent unit. The concentration of $\mathrm{Cl}^{-}, \mathrm{SO}_{4}^{2-}, \mathrm{NO}_{3}^{-}$and $\mathrm{F}^{-}$in the post-monsoon varies from 43-2279, 10-844, 1-160 and $8-30 \mu \mathrm{M}$, respectively. Higher concentration of $\mathrm{Cl}^{-}$in the river water was found at a few locations. In general, $\mathrm{Cl}^{-}$concentration in river water does not exceed dissolved $\mathrm{Na}$ concentration. However, $\mathrm{Cl}^{-}$can be found in excess of $\mathrm{Na}$ in river waters, which may be due to:

(1) precipitation of $\mathrm{Na}$ as salts resulting in enrichment of $\mathrm{Cl}^{-}$in water in arid and semi-arid climate (Sarin et al. 1989; Gaillardet et al. 1999),

(2) contribution of very saline ground water (Gordeev and Sidorov 1993), and

(3) anthropogenic contributions (Rai et al. 2010). Significant contribution of $\mathrm{Cl}^{-}$from anthropogenic activities (effluent discharge) has been reported by Rai et al. (2010) for the Ganga River.

In the Son River water, higher $\mathrm{Cl}^{-}$concentration can be attributed to anthropogenic activities at Diapiper located downstream of a major urban site (Shadol) and dissolution of the precipitated $\mathrm{Na}$ salts in soils, resulting in elevated $\mathrm{Cl}^{-}$ concentration during pre-monsoon. The precipitation of sodium carbonate minerals such as trona $\left(\mathrm{Na}_{2} \mathrm{CO}_{3} \cdot \mathrm{NaHCO}_{3} \cdot 2 \mathrm{H}_{2} \mathrm{O}\right)$ and minor thermonarite $\left(\mathrm{Na}_{2} \mathrm{CO}_{3} \cdot \mathrm{H}_{2} \mathrm{O}\right)$ in alkaline soils of the IndoGangetic plains of India (Datta et al. 2002) can result in the enrichment of $\mathrm{Cl}^{-}$in ground and river water. The oxidative weathering of pyrites associated with coal seams of Gondwanas (Singh and Hasnain 1999) and pyrites present within black shales of the Vindhyan Super Group (Banerjee et al. 2006) could be responsible for higher $\mathrm{SO}_{4}^{2-}$ values in the river water. The higher concentration of $\mathrm{HCO}_{3}^{-}$indicates that significant chemical weathering has been occurring in the Son River catchment. Dissolved silica varies between 219 and $498 \mu \mathrm{M}$ in pre-monsoon and between 153 and $433 \mu \mathrm{M}$ in post-monsoon, which accounts for $9 \%$ of the TDS. The average concentration of dissolved silica $(302.9 \mu \mathrm{M})$ is higher than the Indian average of $116.5 \mu \mathrm{M}$ (Subramanian et al. 1987) and global average value of $179.7 \mu \mathrm{M}$ (Meybeck et al. 1996). 
A high concentration of dissolved silica in the Son River water reflects contribution from weathering of silicate rocks. The alkaline nature of river water enhances the solubility of silica and favours release of silica into solution during silicate weathering (Krauskopf 1959). Major cations constitute around $23 \%$ of the total dissolved loads. $\mathrm{Ca}^{2+}$ and $\mathrm{Mg}^{2+}$ are the dominant cations accounting for 52 and $25 \%$ of the total cations charge balance $\left(\mathrm{TZ}^{+}\right)$, respectively. Concentration of $\mathrm{Ca}^{2+}$ ranges from 220 to $3640 \mu \mathrm{M}$ during the pre-monsoon and $175-$ $1312 \mu \mathrm{M}$ in the post-monsoon, with an average value of $743.6 \mu \mathrm{M}$ and $698.6 \mu \mathrm{M}$, respectively. $\mathrm{Na}^{+}$ concentration varies between 113 and $4167 \mu \mathrm{M}$ (average $674.2 \mu \mathrm{M}$ ) and 91 and $1827 \mu \mathrm{M}$ (average $517.6 \mu \mathrm{M})$ in the pre- and post-monsoon seasons, respectively. The concentration of $\mathrm{Mg}^{2+}$ and $\mathrm{K}^{+}$ in the pre-monsoon varies from 99 to $876 \mu \mathrm{M}$ and 5-312 $\mu \mathrm{M}$, and from 95 to $518 \mu \mathrm{M}$ and $27-127 \mu \mathrm{M}$ in the post-monsoon, respectively.

Table 2 summarizes the average chemical composition of the Son River, some selected Indian rivers and average values of Indian and global rivers. TDS and $\mathrm{HCO}_{3}^{-}$values of the Son River water is significantly higher than those of the Indian and world averages, while $\mathrm{Ca}^{2+}, \mathrm{Mg}^{2+}, \mathrm{Na}^{+}, \mathrm{K}^{+}, \mathrm{Cl}^{-}$and $\mathrm{SO}_{4}^{2-}$ values are nearly equal to the Indian average but much higher than the world average (table 2). The higher concentration of dissolved silica of the Son River than those of Indian and world average is attributed to contribution from silicate weathering in the drainage basin.

\subsection{Seasonal and spatial variations in major ions}

Spatial and temporal variations in physical and chemical parameters are important for the assessment of factors controlling surface water composition. Figure 2 shows the seasonal variations of average concentration of measured parameters in the Son River water. The average $\mathrm{pH}$ is slightly higher in the pre-monsoon season than in the post-monsoon season. The low values of EC and TDS during post-monsoon and higher values in the pre-monsoon period are common phenomena which indicate an increased concentration of major ions during the pre-monsoon period. Calcium, $\mathrm{Na}^{+}, \mathrm{Cl}^{-}, \mathrm{F}^{-}$and dissolved silica follow a similar trend as EC and TDS, i.e., higher concentration in the pre-monsoon which decreases in the post-monsoon period (table 1a). Seasonal variations in the concentration of dissolved constituents in the Son River can be attributed to evaporation effect or contribution from ground water during the lean flow period in the premonsoon and dilution effects of atmospheric precipitation in the post-monsoon season (Singh and Hasnain 1999). The ground water inherits ions during mineral-water interaction in the soil/sediment deposits. The average concentration of bicarbonate and nitrate shows slightly higher values during post-monsoon ( 2155 and $24.2 \mu \mathrm{M}$ ) as compared to pre-monsoon (1955 and $11.29 \mu \mathrm{M})$. The increase in $\mathrm{HCO}_{3}^{-}$concentration can be attributed to seasonal variability in chemical weathering of carbonate and silicate minerals (Tipper et al. 2006) or redissolution of precipitated salt in the post-monsoon season induced by rain water and water level rise (Rengarajan et al. 2009). However, increase in $\mathrm{NO}_{3}^{-}$concentration may be attributed to degradation of organic matter and/or anthropogenic sources including runoff from surrounding agricultural fields and untreated sewage (Sharma and Subramanian 2008). There is no significant variation in the concentration of $\mathrm{Mg}^{2+}, \mathrm{K}^{+}$and $\mathrm{SO}_{4}^{2-}$, reflecting their conservative behaviour in the basin.

The lowest concentrations of dissolved ions are found near the origin of the river at the Amarkantak site. No specific trend of spatial or downstream variation is observed in this study except increase

Table 2. Average composition of Son River water and its comparison with other river basins.

\begin{tabular}{lrrrrrrrrrl}
\hline Rivers & $\mathrm{HCO}_{3}$ & $\mathrm{Cl}$ & $\mathrm{SO}_{4}$ & Silica & $\mathrm{Ca}$ & $\mathrm{Mg}$ & $\mathrm{Na}$ & $\mathrm{K}$ & $\mathrm{TDS}$ & Reference \\
\hline Son & 125 & 18 & 10 & 18 & 29 & 8 & 14 & 3 & 227 & This study \\
Damodar & 94 & 11 & 21 & 22 & 15 & 9 & 16 & 4 & 191 & Singh and Hasnain (1999) \\
Krishna & 178 & 38 & 49 & 24 & 29 & 8 & 30 & 2.4 & 360 & Ramesh and Subramanian (1988) \\
Cauvery & 135 & 20 & 13 & 23 & 21 & 9 & 43 & 4 & 272 & Ramanathan et al. (1994) \\
Godavari & 105 & 17 & 8 & 10 & 22 & 5 & 12 & 3 & 181 & Biksham and Subramanian (1988) \\
Mahanadi & 122 & 23 & 3 & 17 & 24 & 13 & 14 & 8.3 & 224 & Chakrapani and Subramanian (1990) \\
Indus & 64 & 9 & 15 & 5 & 27 & 1 & 1 & 2.1 & 122 & Subramanian (1983) \\
Ganges & 128 & 10 & 11 & 18 & 25 & 8 & 11 & 3 & 214 & Subramanian (1983) \\
Brahmaputra & 38 & 15 & 10 & 7 & 29 & 7 & 12 & 2.5 & 148 & Subramanian (1983) \\
Narmada & 225 & 20 & 5 & 9 & 14 & 20 & 27 & 2 & 322 & Subramanian (1983) \\
Indian avg. & 74 & 15 & 13 & 7 & 30 & 7 & 12 & 3 & 159 & Subramanian (1983) \\
World avg. & 62 & 4 & 9 & 12 & 16 & 4 & 4 & 1.5 & 115 & Sarin et al. (1989) \\
\hline
\end{tabular}

Units: Ionic concentrations in $\mathrm{mg} \mathrm{l}^{-1}$. 


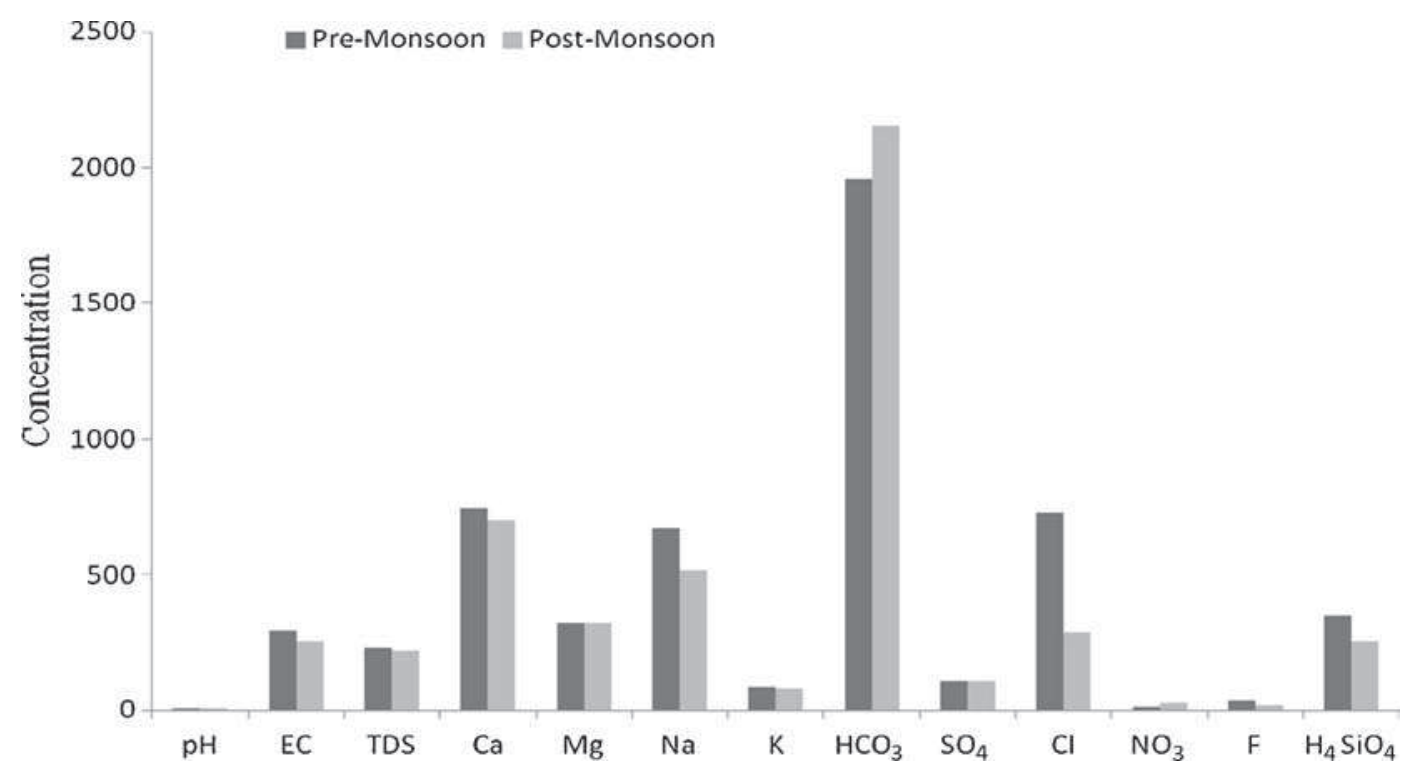

Figure 2. Seasonal variations in the concentration of measured parameters. All parameters except $\mathrm{pH}, \mathrm{EC}(\mu \mathrm{S} / \mathrm{cm})$ and $\operatorname{TDS}(\mathrm{mg} / \mathrm{l})$ are in $\mu \mathrm{M}$.

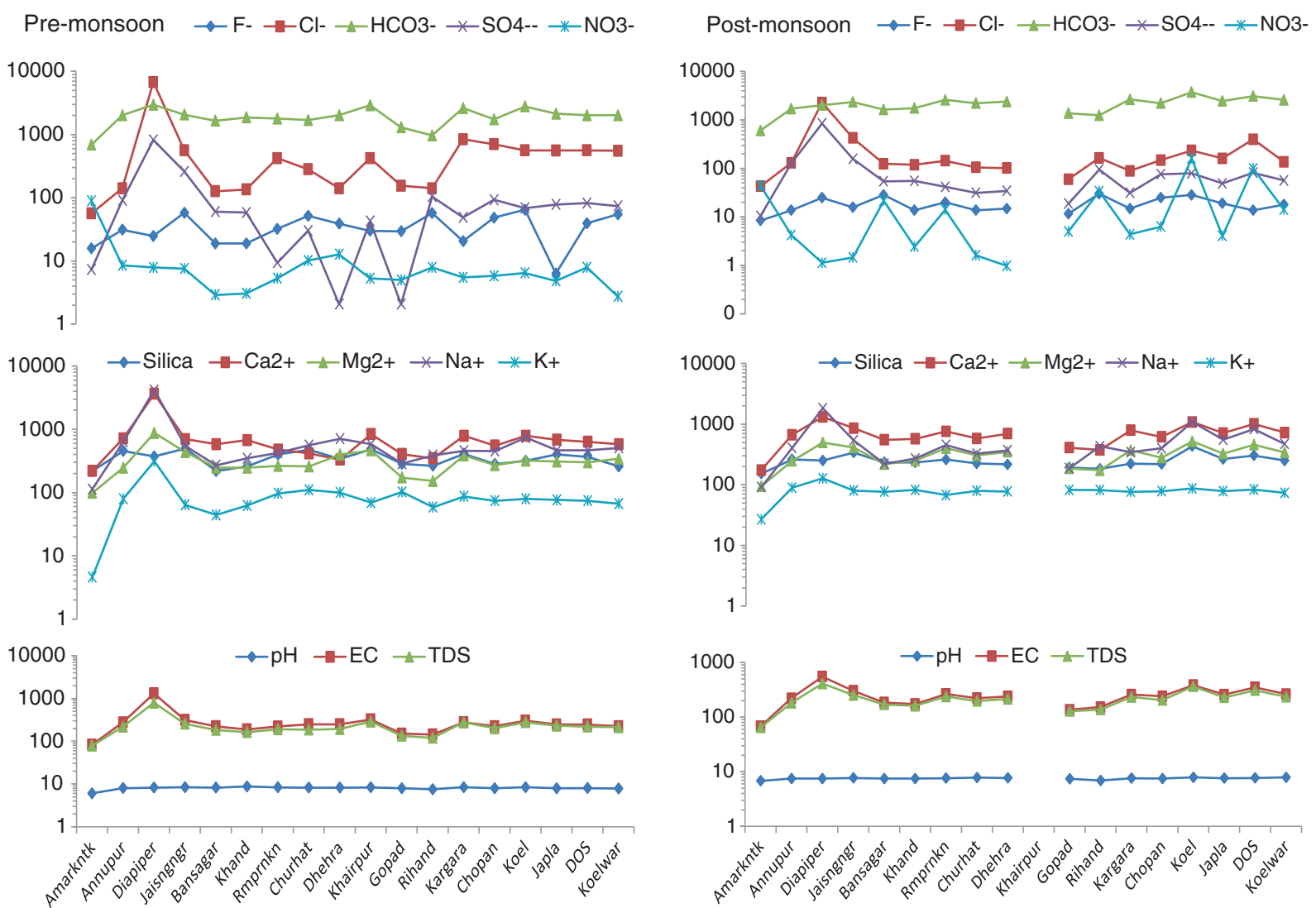

Figure 3. Spatial variations in the concentration of measured parameters $\left(\mathrm{Ca}^{2+}, \mathrm{Mg}^{2+}, \mathrm{Na}^{+}, \mathrm{K}^{+}, \mathrm{H}_{4} \mathrm{SiO}_{4}, \mathrm{~F}^{-}, \mathrm{Cl}^{-}\right.$, $\mathrm{HCO}_{3}^{-}, \mathrm{SO}_{4}^{2-}$ and $\mathrm{NO}_{3}^{-}$in $\mu \mathrm{M}, \mathrm{EC}$ in $\mu \mathrm{S} / \mathrm{cm}$ and $\mathrm{TDS}$ in $\left.\mathrm{mg} / \mathrm{l}\right)$.

in concentrations of TDS, $\mathrm{Cl}^{-}, \mathrm{SO}_{4}^{2-}, \mathrm{Ca}^{2+}, \mathrm{Na}^{+}$ and $\mathrm{K}^{+}$at sites 3 and 15 , and decrease at sites 6 , 11 and 12 (figure 3). The observed spatial variations in solute concentration could be related to the effects of tributaries inflow, changes in lithology, anthropogenic inputs and presence of reservoirs/ dams upstream. The observed higher concentration of most of the dissolved species at site 3 (Diapiper) may be attributed to very sluggish river flow, contributions from ground water and 
anthropogenic activities. Decrease in ionic concentrations at sites 6 and 12, i.e., downstream reservoirs, indicate dilution effects of the Bansagar and Rihand reservoirs, constructed on the Son and Rihand Rivers, respectively.

\subsection{Weathering and solute acquisition processes}

Chemical weathering of rocks in the catchment area plays an important role in determining the nature and amount of dissolved load carried by rivers. Therefore, dissolved components of rivers become important to characterize the nature and extent of weathering in the drainage basin. The nature of weathering is mainly controlled by lithology, tectonics, vegetation and climate of the drainage basin. However, secondary contribution from atmospheric and anthropogenic sources can also contribute to the chemistry of river water (Meybeck 2005).

Major natural processes determining major ion chemistry of water can be identified by plotting the variations in weight ratios of $\mathrm{Na}^{+}+\mathrm{K}^{+} /\left(\mathrm{Na}^{+}+\mathrm{K}^{+}+\mathrm{Ca}^{2+}\right)$ as a function of the TDS (Gibbs 1970). The plotting of most of the samples in the field of 'weathering dominance' suggests rock weathering as the major mechanism controlling the water composition of the Son River (figure 4). In general, $\mathrm{HCO}_{3}^{-}, \mathrm{Ca}^{2+}$ and $\mathrm{Mg}^{2+}$ in river water are almost entirely derived from rock weathering (Berner and Berner 1987). The plotted points of the majority of the Son River

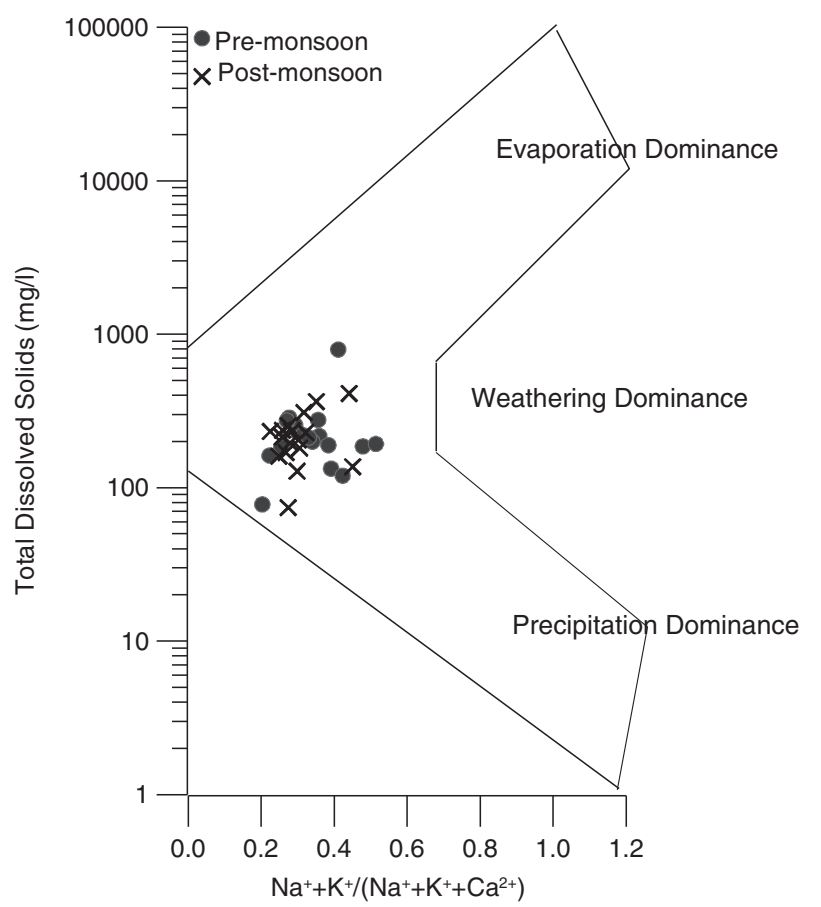

Figure 4. Variation of the weight ratio of $\mathrm{Na} /(\mathrm{Na}+\mathrm{Ca})$ as a function of TDS (after Gibbs 1970). water samples on the variation diagram relating $\left(\mathrm{Ca}^{2+}+\mathrm{Mg}^{2+}\right)$ and $\left(\mathrm{HCO}_{3}^{-}+\mathrm{SO}_{4}^{2-}\right)$ fall along the 1:1 equiline (figure 5a). This may be due to the dissolution of calcite, dolomite and gypsum as the major process in the system (Cerling et al. 1989; Fisher and Mullican 1997). The stoichiometry of carbonate weathering reaction demands that carbonate derived $\mathrm{Ca}^{2+}$ and $\mathrm{Mg}^{2+}$ should be equal to the carbonate derived bicarbonate $\left(\mathrm{HCO}_{3}^{-}\right)$. The analysis shows that in the Son River water $\mathrm{HCO}_{3}^{-}$is slightly enriched than total $\mathrm{Ca}^{2+}$ and $\mathrm{Mg}^{2+}$ as shown in (figure 5b). The above finding suggests that carbonate weathering could be a major contributor for $\mathrm{Ca}^{2+}, \mathrm{Mg}^{2+}$ and $\mathrm{HCO}_{3}^{-}$in the Son River water. Further, the variation plot of $\mathrm{Ca}^{2+}+\mathrm{Mg}^{2+}$ vs. $\mathrm{TZ}^{+}$shows that plotted points fall just below the equiline, indicating significant contribution from $\mathrm{Ca}^{2+}$ and $\mathrm{Mg}^{2+}$ to the total cations $\left(\mathrm{TZ}^{+}\right)$balance, which is also reflected by higher $\mathrm{Ca}^{2+}+\mathrm{Mg}^{2+} / \mathrm{TZ}^{+}$equivalent ratio, i.e. 0.77 (figure 5c). The deviation of plotted points from the equiline at higher concentration indicates an increasing contribution of $\mathrm{Na}^{+}$and $\mathrm{K}^{+}$from silicate weathering or saline/alkaline soil (Rai et al. 2010). It can be suggested that a significant portion of the major ions are probably derived from the weathering of carbonates (dolomites, lime stones) of Vindhyans and silicates rocks (sandstone, shale and volcanoclastics) of Gondwanas, Vindhyans and Mahakoshal group in the Son River basin.

The average $\mathrm{Na}^{+}$concentration in the Son River water is significantly higher than chloride. Higher $\mathrm{Na}^{+}+\mathrm{K}^{+} / \mathrm{Cl}^{-}$equivalent ratio (average 2.68) suggests that much of the alkalis $\left(\mathrm{Na}^{+}+\mathrm{K}^{+}\right)$in the Son River water originates from non-atmospheric sources (figure $5 \mathrm{~d}$ ). The $\mathrm{Na}^{+}+\mathrm{K}^{+} / \mathrm{TZ}^{+}$ratio can also be used as an index to evaluate the contribution of cations through silicate weathering (Stallard and Edmond 1983). The plot of $\mathrm{Na}^{+}+$ $\mathrm{K}^{+}$vs. $\mathrm{TZ}^{+}$and $\mathrm{Na}^{+}+\mathrm{K}^{+} / \mathrm{TZ}^{+}$ratio $(0.23)$ suggest contribution of $\mathrm{Na}^{+}$and $\mathrm{K}^{+}$to the dissolved ions from the weathering of silicates (figure $5 \mathrm{e}$ ). $\mathrm{K}^{+}$ is the least dominant cation and almost constant throughout the drainage basin. Adsorption of $\mathrm{K}^{+}$ ions with the clay minerals seems to be controlling the conservative behaviour of potassium. During continental weathering $\mathrm{Na}^{+}$is more mobile than $\mathrm{K}^{+}$and therefore dominant in the natural solutions (Milliot 1970).

A characteristic feature for rivers with prevailing carbonate weathering in their drainage basin is the predominance of $\mathrm{Ca}^{2+}$ and $\mathrm{Mg}^{2+}$ cations and high $\mathrm{Ca}^{2+}+\mathrm{Mg}^{2+} / \mathrm{Na}^{+}+\mathrm{K}^{+}$ratios. Most of the world's rivers and the major Indian rivers have high $\mathrm{Ca}^{2+}+\mathrm{Mg}^{2+} / \mathrm{Na}^{+}+\mathrm{K}^{+}$ratios, suggesting weathering of carbonate rocks in the catchment area (Subramanian 1979). The $\mathrm{Ca}^{2+}+\mathrm{Mg}^{2+} / \mathrm{Na}^{+}+\mathrm{K}^{+}$ molar abundance ratio in silicates of the upper 

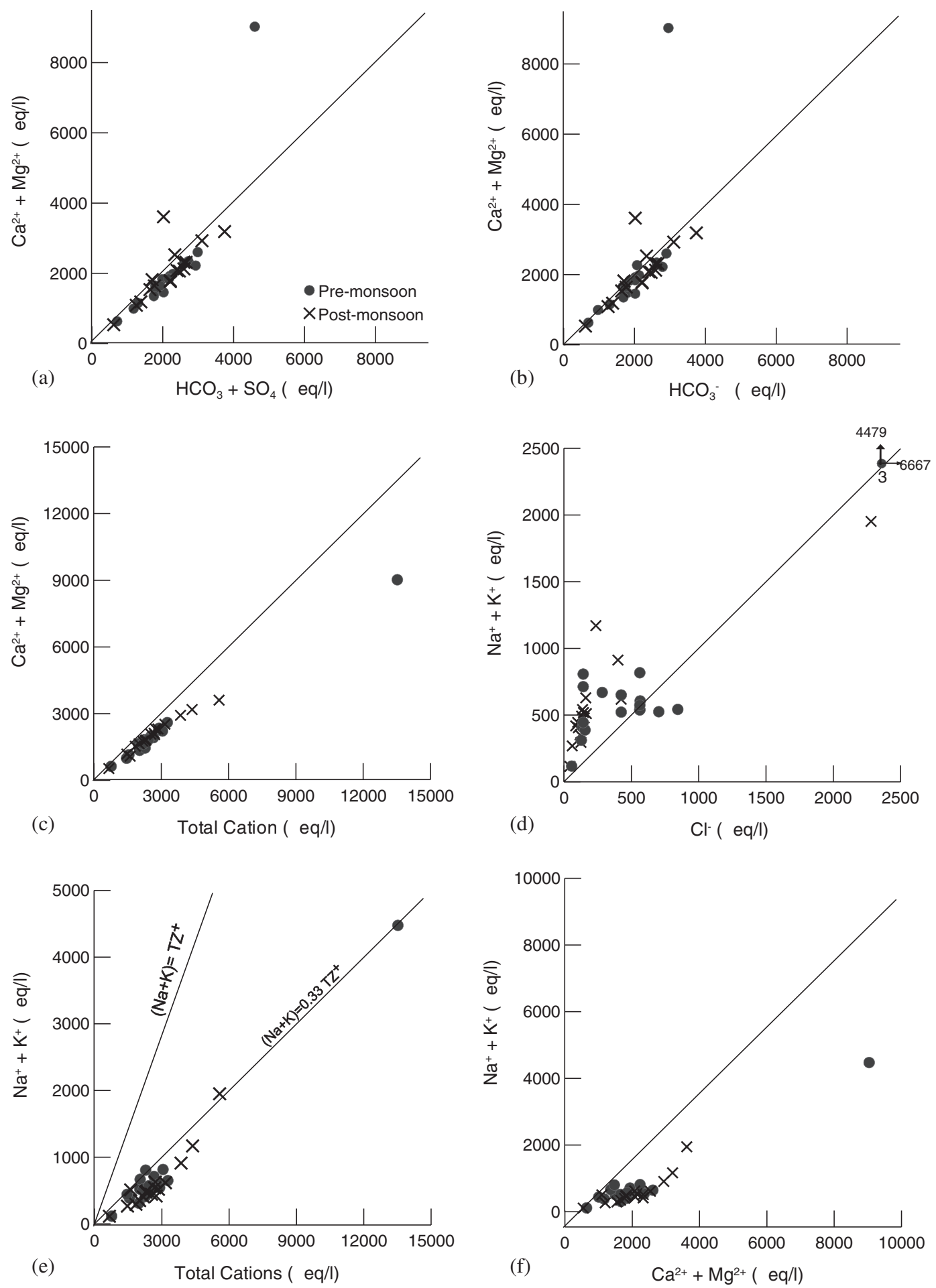

Figure 5. Scatter plots between (a) $\mathrm{Ca}^{2+}+\mathrm{Mg}^{2+}$ vs. $\mathrm{HCO}_{3}^{-}+\mathrm{SO}_{4}^{2-}$, (b) $\mathrm{Ca}^{2+}+\mathrm{Mg}^{2+}$ vs. $\mathrm{HCO}_{3}^{-}$, (c) $\mathrm{Ca}^{2+}+\mathrm{Mg}^{2+}$ vs. $\mathrm{TZ}^{+}$, (d) $\mathrm{Na}^{+}+\mathrm{K}^{+}$vs. $\mathrm{Cl}^{-}$, (e) $\mathrm{Na}^{+}+\mathrm{K}^{+}$vs. $\mathrm{TZ}^{+}$, and (f) $\mathrm{Na}^{+}+\mathrm{K}^{+}$vs. $\mathrm{Ca}^{2+}+\mathrm{Mg}^{2+}$.

crust is generally 1.0 (Taylor and McLennan 1985). The average $\mathrm{Ca}^{2+}+\mathrm{Mg}^{2+} / \mathrm{Na}^{+}+\mathrm{K}^{+}$ratio for the Son River is found to be 3.61, higher than the world (2.2) and the Indian river average (2.5), suggesting that the chemical composition of the Son River is principally controlled by weathering of carbonates (figure 5f). Rai et al. (2010) have reported higher carbonate weathering rate than silicate weathering for the Son River on the basis of their study on tail-end monsoon samples. Our study supports the same for both pre-monsoon and post-monsoon seasons.

The correlation matrix data of major ions and other parameters also substantiate the above 
Table 3. Inter-elemental correlation of geochemical parameters in the Son River water.

\begin{tabular}{|c|c|c|c|c|c|c|c|c|c|c|c|c|c|c|}
\hline & $\mathrm{pH}$ & $\mathrm{EC}$ & TDS & $\mathrm{F}$ & $\mathrm{Cl}$ & $\mathrm{HCO}_{3}$ & $\mathrm{SO}_{4}$ & $\mathrm{NO}_{3}$ & $\mathrm{H}_{4} \mathrm{SiO}_{4}$ & $\mathrm{Ca}$ & $\mathrm{Mg}$ & $\mathrm{Na}$ & $\mathrm{K}$ & $\mathrm{TH}$ \\
\hline \multicolumn{15}{|c|}{ Pre-monsoon } \\
\hline $\mathrm{pH}$ & 1.00 & & & & & & & & & & & & & \\
\hline $\mathrm{EC}$ & 0.24 & 1.00 & & & & & & & & & & & & \\
\hline TDS & 0.32 & 0.98 & 1.00 & & & & & & & & & & & \\
\hline $\mathrm{F}$ & 0.15 & -0.09 & -0.06 & 1.00 & & & & & & & & & & \\
\hline $\mathrm{Cl}$ & 0.13 & 0.98 & 0.95 & -0.12 & 1.00 & & & & & & & & & \\
\hline $\mathrm{HCO}_{3}$ & 0.65 & 0.59 & 0.70 & 0.02 & 0.48 & 1.00 & & & & & & & & \\
\hline $\mathrm{SO}_{4}$ & 0.14 & 0.95 & 0.92 & -0.02 & 0.95 & 0.43 & 1.00 & & & & & & & \\
\hline $\mathrm{NO}_{3}$ & -0.88 & -0.17 & -0.24 & -0.23 & -0.09 & -0.50 & -0.11 & 1.00 & & & & & & \\
\hline $\mathrm{H}_{4} \mathrm{SiO}_{4}$ & 0.64 & 0.26 & 0.34 & 0.18 & 0.13 & 0.61 & 0.17 & -0.57 & 1.00 & & & & & \\
\hline $\mathrm{Ca}$ & 0.22 & 0.98 & 0.97 & -0.16 & 0.98 & 0.58 & 0.95 & -0.16 & 0.19 & 1.00 & & & & \\
\hline $\mathrm{Mg}$ & 0.42 & 0.91 & 0.95 & -0.02 & 0.86 & 0.77 & 0.84 & -0.30 & 0.43 & 0.88 & 1.00 & & & \\
\hline $\mathrm{Na}$ & 0.17 & 0.99 & 0.96 & -0.06 & 0.98 & 0.51 & 0.94 & -0.12 & 0.18 & 0.97 & 0.87 & 1.00 & & \\
\hline $\mathrm{K}$ & 0.31 & 0.93 & 0.91 & -0.05 & 0.92 & 0.51 & 0.85 & -0.29 & 0.32 & 0.90 & 0.83 & 0.94 & 1.00 & \\
\hline $\mathrm{TH}$ & 0.26 & 0.99 & 0.98 & -0.13 & 0.97 & 0.62 & 0.94 & -0.19 & 0.24 & 0.99 & 0.92 & 0.97 & 0.90 & 1.00 \\
\hline \multicolumn{15}{|c|}{ Post-monsoon } \\
\hline $\mathrm{pH}$ & 1.00 & & & & & & & & & & & & & \\
\hline $\mathrm{EC}$ & 0.54 & 1.00 & & & & & & & & & & & & \\
\hline TDS & 0.61 & 0.98 & 1.00 & & & & & & & & & & & \\
\hline $\mathrm{F}$ & 0.02 & 0.34 & 0.35 & 1.00 & & & & & & & & & & \\
\hline $\mathrm{Cl}$ & 0.03 & 0.79 & 0.68 & 0.27 & 1.00 & & & & & & & & & \\
\hline $\mathrm{HCO}_{3}$ & 0.84 & 0.64 & 0.76 & 0.22 & 0.05 & 1.00 & & & & & & & & \\
\hline $\mathrm{SO}_{4}$ & -0.00 & 0.75 & 0.63 & 0.29 & 0.98 & -0.01 & 1.00 & & & & & & & \\
\hline $\mathrm{NO}_{3}$ & 0.12 & 0.23 & 0.36 & 0.28 & -0.06 & 0.48 & -0.12 & 1.00 & & & & & & \\
\hline $\mathrm{H}_{4} \mathrm{SiO}_{4}$ & 0.27 & 0.36 & 0.45 & 0.04 & 0.06 & 0.48 & 0.02 & 0.73 & 1.00 & & & & & \\
\hline $\mathrm{Ca}$ & 0.64 & 0.97 & 0.98 & 0.29 & 0.67 & 0.74 & 0.63 & 0.28 & 0.41 & 1.00 & & & & \\
\hline $\mathrm{Mg}$ & 0.73 & 0.91 & 0.95 & 0.24 & 0.50 & 0.87 & 0.43 & 0.35 & 0.48 & 0.95 & 1.00 & & & \\
\hline $\mathrm{Na}$ & 0.28 & 0.94 & 0.90 & 0.41 & 0.88 & 0.44 & 0.85 & 0.31 & 0.35 & 0.87 & 0.76 & 1.00 & & \\
\hline K & 0.39 & 0.75 & 0.69 & 0.41 & 0.70 & 0.33 & 0.72 & -0.07 & -0.11 & 0.72 & 0.57 & 0.74 & 1.00 & \\
\hline $\mathrm{TH}$ & 0.67 & 0.96 & 0.98 & 0.28 & 0.63 & 0.79 & 0.58 & 0.31 & 0.44 & 0.99 & 0.97 & 0.84 & 0.68 & 1.00 \\
\hline
\end{tabular}

inference (table 3). The observed good correlation between cations, i.e., $\mathrm{Ca}-\mathrm{Mg}$ (pre-monsoon: 0.88, post-monsoon: 0.95), $\mathrm{Ca}-\mathrm{Na}$ (pre-monsoon: 0.97, post-monsoon: 0.87), Ca-K (pre-monsoon: 0.90, post-monsoon: 0.72) and $\mathrm{Na}-\mathrm{K}$ (pre-monsoon: 0.94, post-monsoon: 0.74) suggests a common source for cations. $\mathrm{HCO}_{3}^{-}$has a strong correlation with $\mathrm{Ca}^{2+}$ and $\mathrm{Mg}^{2+}$ and good to fair correlation with $\mathrm{Na}^{+}$and $\mathrm{K}^{+}$reflecting the dissolution of carbonates and weathering of silicates within the basin. The strong correlation of EC with all major ions (except $\mathrm{F}^{-}$and $\mathrm{NO}_{3}^{-}$) due to significant amount of dissolved salt is observed at all sites. Chloride and sulphate show good correlation with each other and also with calcium, magnesium, sodium and potassium indicating a common source, which can be due to dissolution of salts, remobilisation of ions from saline/alkaline soils and/or anthropogenic input (Rengarajan et al. 2009). The moderate correlation between $\mathrm{HCO}_{3}^{-}$and $\mathrm{NO}_{3}^{-}$during post-monsoon suggesting ground water degradation of organic matter or anthropogenic activities as probable sources.

The Piper (1944) diagram is very useful in determining relationships of different dissolved constituents and classification of water on the basis of its chemical character. The triangular cationic fields of Piper diagram reveals that most of the plotted points of the water samples fall into $\mathrm{Ca}^{2+}$, some in $\mathrm{Mg}^{2+}$ and few in no dominant zone, whereas in the anion triangle majority of the samples fall into bicarbonate field. The plot of chemical data on diamond shaped central field reveals the dominance of alkaline earth metals $\left(\mathrm{Ca}^{2+}+\mathrm{Mg}^{2+}\right)$ over alkali metal cations $\left(\mathrm{Na}^{+}+\mathrm{K}^{+}\right)$and weak acid $\left(\mathrm{HCO}_{3}^{-}\right)$over strong acid $\left(\mathrm{SO}_{4}^{2-}+\mathrm{Cl}^{2-}\right)$ in the Son water (figure 6 ). Therefore, according to Back (1966), Ca- $\mathrm{Mg}-\mathrm{HCO}_{3}$ is the dominant hydrogeochemical facies except for a few samples (figure 3 a and b) which plot in the Piper diagram (figure 6) as a mixed chemical character of $\mathrm{Ca}-\mathrm{Mg}-\mathrm{Cl}$ hydrogeochemical facies. 


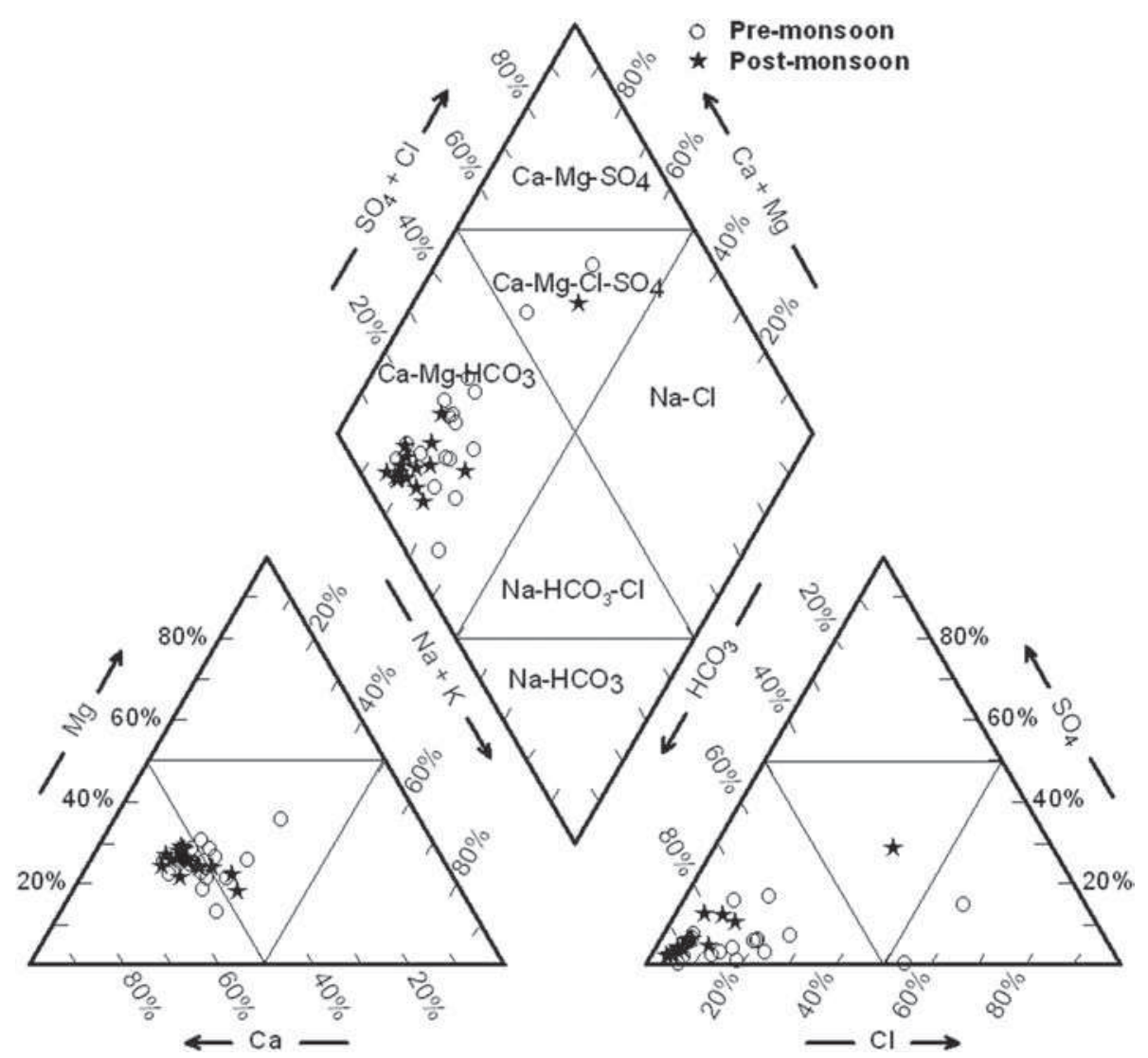

Figure 6. Piper trilinear diagram for hydrochemical facies of Son River water (after Piper 1944).

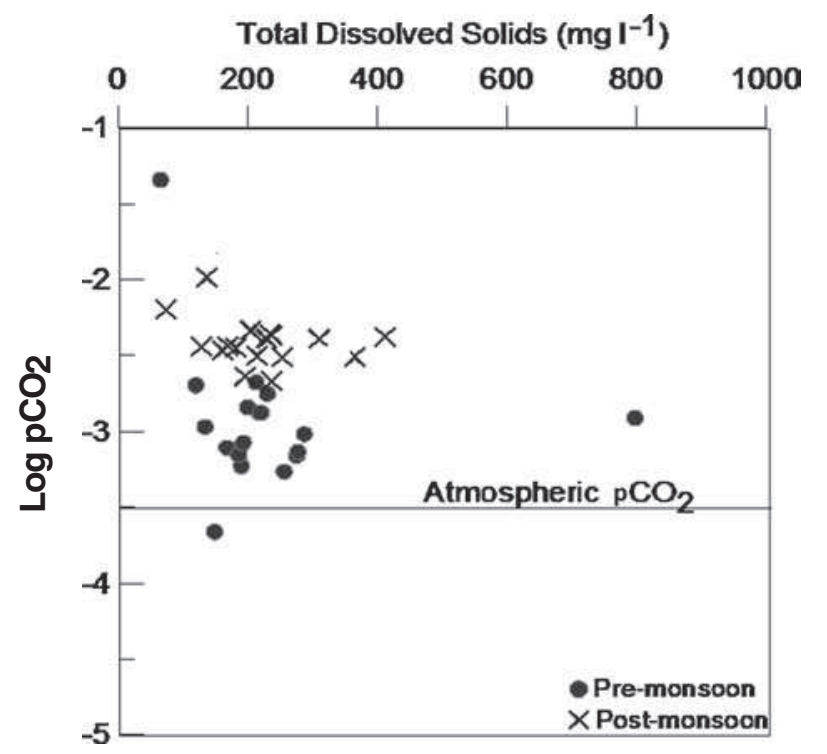

Figure 7. Relationship between $p \mathrm{CO}_{2}$ and total dissolved solids (TDS).

The computed partial pressure $p \mathrm{CO}_{2}$ (Garrels and Christ 1965) for the Son River water (table 1a) is slightly higher $\left(10^{-3.26}-10^{-1.34}\right)$ than the atmospheric level $\left(10^{-3.5}\right)$, except one sample of the Bansagar reservoir (figure 7). The higher $p \mathrm{CO}_{2}$ in the river water is a global trend indicating that the rivers are commonly not in equilibrium with the atmosphere (Garrels and Mackenzie 1971). Slightly higher $p \mathrm{CO}_{2}$ values could be attributed to significant contribution from $\mathrm{CO}_{2}$-rich groundwater to the river channel. The re-equilibration with the atmosphere is achieved by slow release of excess $\mathrm{CO}_{2}$ (Holland 1978; Stumm and Morgan 1981). The equilibrium state of the water with respect to a mineral phase can be determined by calculating a saturation index (SI) using analytical data (Stumm and Morgan 1981). The plot of saturation index of calcite $\left(\mathrm{SI}_{\mathrm{c}}\right)$ vs. dolomite $\left(\mathrm{SI}_{\mathrm{d}}\right)$ demonstrate that most of the post-monsoon samples are in undersaturated condition, while majority of the premonsoon water samples are supersaturated with respect to both calcite and dolomite (figure 8). The supersaturation shows the evaporation effects during the lean water level period of the pre-monsoon, which favours precipitation of carbonates (Hardie and Eugster 1970).

\subsection{Principal component analysis}

The principal component analysis is useful in identifying and interpreting relations among different parameters of river water, reflecting the variance 
of a large set of inter-correlated variables by condensing a larger data set into a smaller set of independent components with a minimum loss of original information (Bhardwaj et al. 2010). The principal component analysis for the Son River water is given in table 4 . The data matrix of 14 parameters and 35 observations has been used in the present study. It shows that the first three principal components together accounts for $85.854 \%$ of the total variance in the dataset, in which the first principal component accounts for $61.746 \%$,

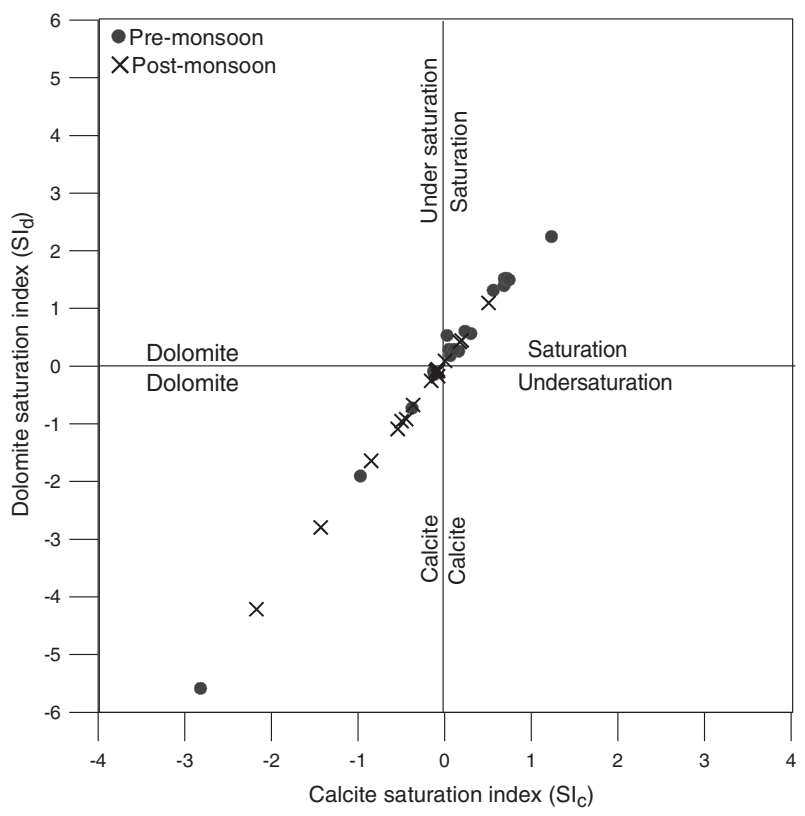

Figure 8. Plot of saturation indices $(\mathrm{SI})$ of dolomite $\left(\mathrm{SI}_{\mathrm{d}}\right)$ vs. calcite $\left(\mathrm{SI}_{\mathrm{C}}\right)$. second principal component accounts for $14.178 \%$ and the third principal component accounts for $9.930 \%$ of the total variance. Values of the communality for all variables (14) and the eigen values $(>1)$ of the first three principal components can be applied to identify the dominant hydrogeochemical processes. In the first principal component, the values of EC, $\mathrm{Cl}^{-}, \mathrm{Na}^{+}, \mathrm{Ca}^{2+}$, TH, TDS, $\mathrm{SO}_{4}^{2-}, \mathrm{K}^{+}$and $\mathrm{Mg}^{2+}$ show high positive loading, whereas values of $\mathrm{HCO}_{3}^{-}, \mathrm{H}_{4} \mathrm{SiO}_{4}$ and $\mathrm{pH}$ have low positive loading. Fluoride and nitrate have very low to negative loading. The high positive loading of $\mathrm{EC}, \mathrm{Na}^{+}, \mathrm{Ca}^{2+}, \mathrm{Mg}^{2+}, \mathrm{K}^{+}$, TH, TDS, $\mathrm{Cl}^{-}$ and $\mathrm{SO}_{4}^{2-}$ ions on the first principal component suggests that this component is associated with weathering and solute acquisition processes in the catchment.

The second principal component has high to moderate positive loading of $\mathrm{pH}, \mathrm{H}_{4} \mathrm{SiO}_{4}, \mathrm{~F}^{-}$, $\mathrm{HCO}_{3}^{-}$and low positive loading of TDS and $\mathrm{Mg}^{2+}$, while others have negative loading. The association of $\mathrm{F}^{-}$and $\mathrm{H}_{4} \mathrm{SiO}_{4}$ in water may be due to the ionic exchange of $\mathrm{F}^{-}$and $\mathrm{OH}^{-}$on the clay minerals (Subba Rao and Devadas 2003). It also appears that the association of $\mathrm{HCO}_{3}^{-}, \mathrm{F}^{-}$and silica with $\mathrm{pH}$ seems to play a role here. The third principal component has high positive loading of $\mathrm{NO}_{3}^{-}$ and moderate positive loading of $\mathrm{HCO}_{3}^{-}$, while others have low to negative loading. The covariance of bicarbonate and nitrate in the water can be attributed to a common source likely to be the ground water, affected by organic matter decomposition and/or anthropogenic activities (irrigation return flow/agricultural runoff, fertilizers and sewage).

Table 4. Principal and rotated component matrix.

\begin{tabular}{|c|c|c|c|c|c|c|c|}
\hline \multirow[b]{2}{*}{ Parameters } & \multicolumn{3}{|c|}{ Principal component matrix } & \multirow[b]{2}{*}{ Communality } & \multicolumn{3}{|c|}{ Rotated component matrix } \\
\hline & $\mathrm{I}$ & II & III & & $\mathrm{I}$ & II & III \\
\hline $\mathrm{EC}$ & 0.992 & -0.091 & -0.031 & 0.993 & 0.978 & 0.172 & 0.086 \\
\hline TDS & 0.992 & 0.006 & 0.099 & 0.994 & 0.937 & 0.271 & 0.208 \\
\hline $\mathrm{TH}$ & 0.986 & -0.903 & 0.068 & 0.985 & 0.96 & 0.173 & 0.184 \\
\hline $\mathrm{Ca}$ & 0.975 & -0.15 & 0.024 & 0.973 & 0.97 & 0.113 & 0.142 \\
\hline $\mathrm{Mg}$ & 0.926 & 0.14 & 0.23 & 0.93 & 0.822 & 0.387 & 0.322 \\
\hline $\mathrm{Na}$ & 0.966 & -0.163 & -0.072 & 0.966 & 0.977 & 0.095 & 0.047 \\
\hline $\mathrm{K}$ & 0.907 & -0.076 & -0.197 & 0.867 & 0.913 & 0.16 & -0.089 \\
\hline $\mathrm{Cl}$ & 0.927 & -0.219 & -0.225 & 0.959 & 0.973 & 0.026 & -0.106 \\
\hline $\mathrm{SO}_{4}$ & 0.808 & -0.283 & -0.27 & 0.807 & 0.881 & -0.069 & -0.160 \\
\hline $\mathrm{HCO}_{3}$ & 0.587 & 0.389 & 0.592 & 0.846 & 0.388 & 0.55 & 0.627 \\
\hline $\mathrm{H}_{4} \mathrm{SiO}_{4}$ & 0.361 & 0.752 & 0.089 & 0.704 & 0.141 & 0.823 & 0.080 \\
\hline $\mathrm{F}$ & 0.053 & 0.57 & -0.383 & 0.474 & -0.048 & 0.551 & -0.411 \\
\hline $\mathrm{NO}_{3}$ & -0.019 & -0.212 & 0.798 & 0.683 & -0.063 & -0.183 & 0.804 \\
\hline $\mathrm{pH}$ & 0.386 & 0.823 & -0.107 & 0.838 & 0.171 & 0.892 & -0.117 \\
\hline Eigenvalues & & & & & 8.644 & 1.985 & 1.39 \\
\hline Variance $(\%)$ & & & & & 61.746 & 14.178 & 9.93 \\
\hline Cumulative $\%$ of variance & & & & & 61.746 & 75.924 & 85.854 \\
\hline
\end{tabular}




\subsection{Dissolved fluxes and chemical denudation rate $(C D R)$}

It is essential to estimate the elemental fluxes of rivers to understand the nature and extent of elemental dynamics from continent to river and ocean systems. This helps in quantifying the global riverine geochemical budget. Studies are available on fluvial mass transport by a number of researchers during past few decades with an attempt to quantify global riverine fluxes (Meybeck 1976; Martin and Meybeck 1979; Subramanian 1979, 1984; Hu et al. 1982; Sarin et al. 1989; Krishnaswami et al. 1992; Rai et al. 2010; Gupta et al. 2011; Yadav and Chakrapani 2011). An attempt has been made to estimate the average annual fluxes of dissolved major ions and chemical denudation rate (CDR) of the Son River basin. Here, we have used the discharge and drainage data reported by Rao (1975) for flux and CDR calculation. The data of Rao (1975) is used by this and other studies because of unavailability of discharge data for regulatory reasons. In earlier studies, the average annual (average of monsoon and non-monsoonal months) discharge data of Rao (1975) and water chemistry of mainly monsoon season was used to quantify the flux, which ultimately have given monsoon biased results. Again, the discharge during monsoon and non-monsoon varies for different river basins depending upon the sources (glacial/non-glacial) and interannual variability of precipitation. Here, we have adopted an approach similar to that of Sarin and Krishnaswami (1984) for flux and CDR calculation. Rao (1975) has reported that most of the water discharge occurs during the monsoon $(>90 \%)$ and the rest during the nonmonsoon seasons $(>10 \%)$. Therefore, for the calculation of flux and CDR we have given 90\% weightage to monsoon and $10 \%$ to non-monsoon, i.e. pre-monsoon and post-monsoon seasons for the annual average discharge. Chemical composition of non-monsoon (average of pre-monsoon 2013 and post-monsoon 2010, assuming that not much change has occurred during this period) and monsoon-2013 samples are used for flux and CDR calculation (table 1b). The calculated annual fluxes of major ions, total solute flux and CDR of the Son River along with some other rivers of the Ganga basin are given in table 5. The Son River annually delivers 4.2 million tons of dissolved loads at Koelwar with 3.6 million tons $\mathrm{yr}^{-1}$ during monsoon and 0.6 million tons $\mathrm{yr}^{-1}$ during non-monsoon seasons, respectively. The chemical denudation rate of the Son River basin is estimated at 59.5 tons $\mathrm{km}^{-2} \mathrm{yr}^{-1}$ with a value of 50.5 tons $\mathrm{km}^{-2} \mathrm{yr}^{-1}$ during monsoon and 9 tons $\mathrm{km}^{-2} \mathrm{yr}^{-1}$ in non-monsoon seasons. The present estimation of flux and CDR is without correction

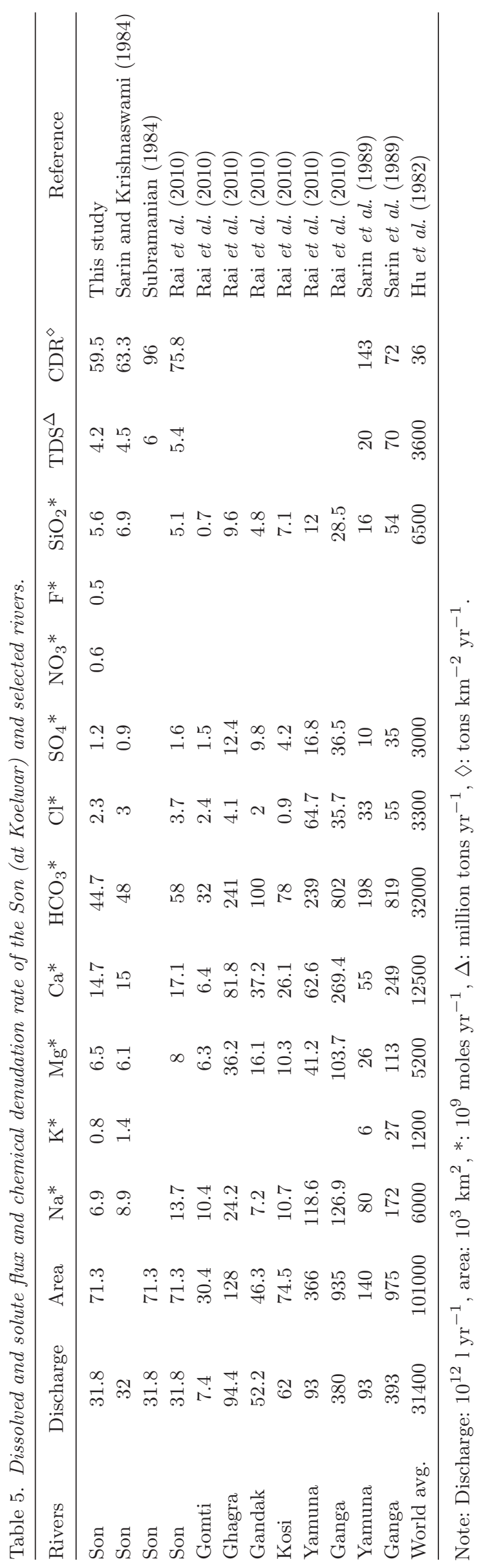


for atmospheric input, as the atmospheric input is negligible during the study period as discussed earlier in section 4.3. Thus, the variation in dissolved fluxes and CDR values during monsoon and nonmonsoon periods highlight the importance of water discharge and measured concentration of various elements, which is controlled by differential weathering behaviour of various lithologies, seasonal variations in evaporation, precipitation and/or dissolution of minerals/salts, ground water contribution and anthropogenic activities in different seasons.

The dissolved flux data of the Son River reflect that the river contributes a total of $\sim 6 \%$ (4.2 million tons $\mathrm{yr}^{-1}$ ) of the dissolved load transported by the Ganga river (70 million tons $\mathrm{yr}^{-1}$; Sarin et al. 1989) to the Bay of Bengal, while the drainage area and water discharge of the Son is, respectively, $7 \%$ and $8 \%$ of that of the Ganga River. The contribution of individual ionic species to total dissolved flux by the Son River are as follows: $\mathrm{Na}^{+}(8 \%)$, $\mathrm{K}^{+}(1 \%), \mathrm{Mg}^{2+}(8 \%), \mathrm{Ca}^{2+}(17.5 \%), \mathrm{HCO}_{3}^{-}(53 \%)$, $\mathrm{Cl}^{-}(3 \%), \mathrm{SO}_{4}^{2-}(1.4 \%), \mathrm{F}^{-}(0.6 \%), \mathrm{NO}_{3}^{-}(0.7 \%)$ and $\mathrm{H}_{4} \mathrm{SiO}_{4}(7 \%)$. The annual average major ion fluxes, total solute load and CDR of the Son River show lower values compared to the result of Rai et al. (2010) and Sarin et al. (1989). This difference can be ascribed to the different approaches adopted by authors to calculate flux and CDR, and to the yearly or seasonal variation in the concentration of dissolved ions. However, comparison of the measured concentration of dissolved ions with that of Rai et al. (2010) and Sarin et al. (1989) does not show much difference during monsoon season (table 1b). Our study emphasizes the importance of the methodology/approach used for flux and CDR estimation.

\subsection{Water quality assessment}

The parameters such as sodium absorption ratio $(\mathrm{SAR})$, percent sodium $(\% \mathrm{Na})$ and residual sodium carbonate (RSC) were estimated to assess the suitability of the Son River water for irrigation purpose (table 1a). EC and Na concentration are very important in classifying irrigation water. The total concentration of soluble salts in irrigation water can be expressed for the purpose of classification of irrigation water as low $\left(\mathrm{EC} \leq 250 \mu \mathrm{S} \mathrm{cm}{ }^{-1}\right.$ ), medium (250-750 $\left.\mu \mathrm{S} \mathrm{cm} \mathrm{cm}^{-1}\right)$, high $(750-2250 \mu \mathrm{S}$ $\left.\mathrm{cm}^{-1}\right)$ and very high $\left(2250-5000 \mu \mathrm{S} \mathrm{cm}^{-1}\right)$ salinity zones (Wilcox 1955). Irrigation water with a high salt concentration results in the formation of saline soil, whereas a high sodium concentration leads to development of alkaline soil. The sodium or alkali hazard occurrence is determined by the absolute and relative concentration of cations and expressed in terms of sodium absorption ratio (SAR).
On the basis of SAR value, water can be classified as low (SAR $<6)$, medium $(6-12)$, high (12$18)$ and very high $(>18)$ alkali water. The calculated value of SAR in the study area varies from 0.20 to 1.96 in the pre-monsoon and 0.17 to 1.36 in the post-monsoon periods. The plot of data on the US salinity diagram in which the EC is taken as salinity hazard and SAR as alkalinity hazard shows that most of the surface water samples fall in the category C1S1 and C2S1 (Richards 1954), indicating low to medium salinity and low sodium water, which can be used for irrigation with little danger of development of exchangeable sodium and salinity (figure 9).

Sodium concentration is important in classifying irrigation water because sodium reacts with soil to reduce its permeability. Excess sodium in water produces undesirable effects of changing soil properties and reducing soil permeability (Kelley 1951). The $\% \mathrm{Na}$ of the surface water in the study area ranges between 15.7 and 35.6 in the premonsoon and between 15.4 and 35.1 in the postmonsoon. According to Bureau of Indian Standard (BIS 2004), maximum percent sodium of $60 \%$ is recommended for irrigation water. A plot of analysed data on the Wilcox (1955) diagram relating $\mathrm{EC}$ and $\% \mathrm{Na}$ shows that the water is good to excellent for irrigation (figure 10).

The quantity of bicarbonate and carbonate in excess of alkaline earths $\left(\mathrm{Ca}^{2+}+\mathrm{Mg}^{2+}\right)$ also influence the suitability of water for irrigation purposes. When the sum of $\mathrm{CO}_{3}^{2-}$ and $\mathrm{HCO}_{3}^{-}$is excess over

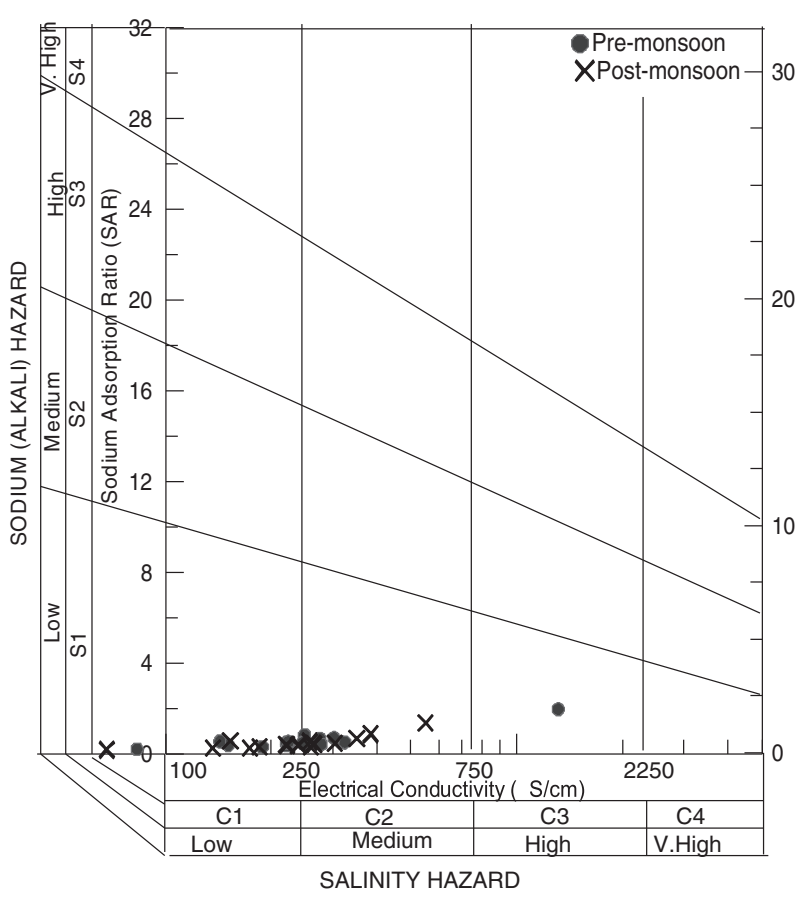

Figure 9. USSL salinity diagram of Son River water for classification of irrigation water (after Richards 1954). 


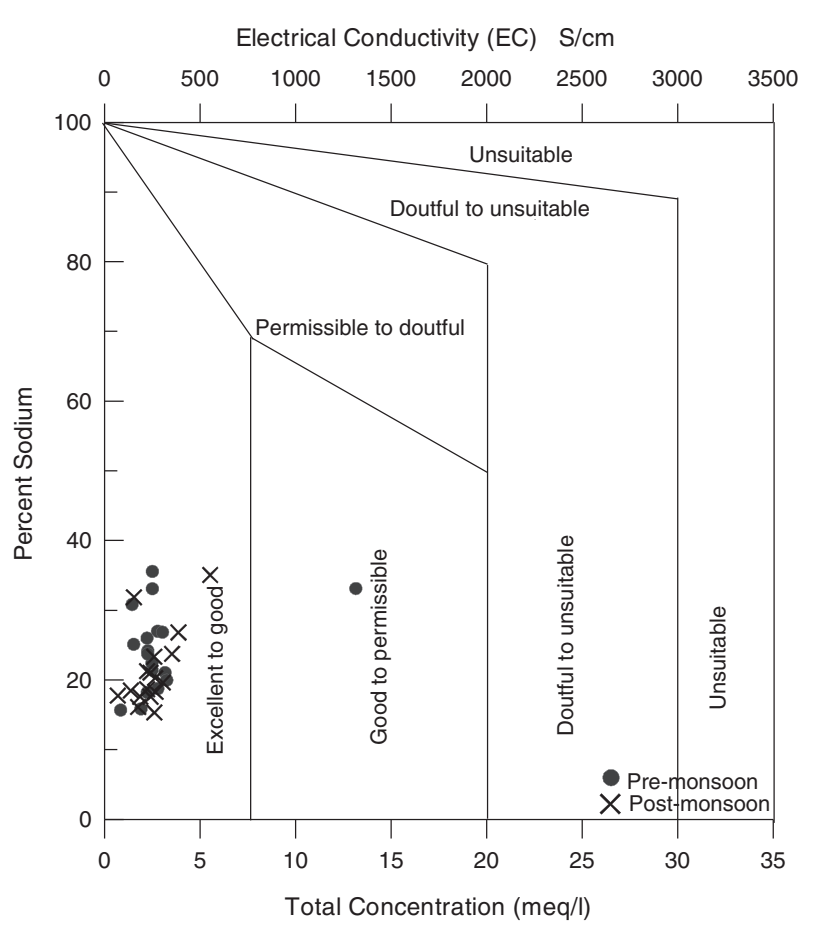

Figure 10. Wilcox diagram for classification of Son River water based on EC and \% Na (after Wilcox 1955).

$\mathrm{Ca}^{2+}$ and $\mathrm{Mg}^{2+}$, there may be possibility of complete precipitation of $\mathrm{Ca}^{2+}$ and $\mathrm{Mg}^{2+}$ as carbonates (Karanth 1989). The effects of carbonate and bicarbonate can be assessed by estimating residual sodium carbonate $\left(\mathrm{RSC}=\mathrm{CO}_{3}^{2-}+\mathrm{HCO}_{3}^{-}-\right.$ $\mathrm{Ca}^{2+}+\mathrm{Mg}^{2+}$, all concentration in meq/l). A high value of RSC in water leads to an increase in the adsorption of sodium on soil (Eaton 1950). Irrigation water having RSC values greater than 5 meq $\mathrm{l}^{-1}$ has been considered harmful to the growth of plants, while waters with RSC values above $2.5 \mathrm{meq}^{-1}$ is not suitable for irrigation purpose. The RSC value of the Son River water samples varies from -6.08 to $0.58 \mathrm{meq}^{-1}$ in pre-monsoon and -1.60 to 0.55 meq $\mathrm{l}^{-1}$ in post-monsoon season. The low RSC $\left(<1.25\right.$ meq $\left.\mathrm{l}^{-1}\right)$ values suggest that the Son River water is safe and suitable for irrigation uses. Also to assess the suitability for drinking water purposes, the measured hydrochemical parameters of the Son River water were compared with guidelines values of WHO (2004) and BIS (2004), which shows that values are within the maximum permissible limit and suitable for drinking purposes.

\section{Conclusions}

The present study shows that the Son River water is alkaline in nature, and $\mathrm{Ca}^{2+}, \mathrm{Mg}^{2+}$ and $\mathrm{HCO}_{3}^{-}$are the predominant dissolved ions. The water chemistry is primarily controlled by rock weathering with secondary contributions from ground water, saline/alkaline soils and anthropogenic sources. The chemical composition of Son River water reflects the influence of both carbonate and silicate weathering, with the dominance of carbonate dissolution in controlling the water chemistry. The Son River water is supersaturated with respect to calcite and dolomite in the pre-monsoon and undersaturated in the remaining seasons of the year. The higher concentration of most of the measured parameters at Diapiper reflects the impact of anthropogenic activities.

The Son River delivers about 4.2 million tons of dissolved loads annually to the Ganga River, which accounts for $\sim 6 \%$ of the total annual load carried by the Ganga River to the Bay of Bengal. The Son River has lower solute flux, but higher CDR (59.5 tons $\left.\mathrm{km}^{-2} \mathrm{yr}^{-1}\right)$ compared to the world average (36 tons $\left.\mathrm{km}^{-2} \mathrm{yr}^{-1}\right)$. Values of solute flux and CDR during non-monsoon and post-monsoon highlight a strong seasonal control. The difference observed for the values of solute flux and CDR of the Son River between the present and earlier studies shows the importance of the methodology adopted for flux and CDR estimation. The measured hydrochemical parameters, sodium adsorption ratio (SAR), percent sodium (\% $\mathrm{Na}$ ) and residual sodium carbonate (RSC) indicate that Son River water is good to excellent in quality for irrigation and also can safely be used for drinking purposes. The study provides an insight into the contribution of small/medium size river to a large river system, with a need to investigate their role in a more detailed and systematic way.

\section{Acknowledgements}

CM and SKG thank the Council of Scientific and Industrial Research for financial support in the form of a research fellowship. JKT thanks DST for financial assistance in maintaining the geochemical lab. The Dean, School of Environmental Sciences, Jawaharlal Nehru University, and the Director, Central Institute of Mining and Fuel Research, are acknowledged for their help. Authors also thank D Shankar for his editorial handling and valuable suggestions, and the anonymous reviewers for their constructive comments that helped in improving the quality of this paper.

\section{References}

Ahmad T, Khanna P, Chakrapani G J and Balakrishnan S 1998 Geochemical characteristics of water and sediment of the Indus river, Trans-Himalaya, India: Constraints on weathering and erosion; J. Asian Earth Sci. 16 333-346. 
APHA 1998 Standard methods for the examination of water and waste water, 20th edn; American Public Health Association, Washington, DC.

Back W 1966 Hydrochemical facies and groundwater flow pattern in northern part of Atlantic coastal plain; USGS Series Professional Paper; 498-A, 42p.

Banerjee S, Dutta S, Paikaray S and Mann U 2006 Stratigraphy, sedimentology and bulk organic geochemistry of black shales from the Proterozoic Vindhyan Supergroup (central India); J. Earth Syst. Sci. 115 37-47.

Berner E K and Berner R A 1987 The global water cycle: Geochemistry and environment; Prentice-Hall, Englewood Cliffs.

Bhardwaj V, Singh D S and Singh A K 2010 Water quality of the Chotti Gandak river using principal component analysis, Ganga plain, India; J. Earth Syst. Sci. 119 117-127.

Biksham G and Subramanian V 1988 Nature of solute transport in the Godavari basin, India; J. Hydrol. 103 375-392.

Bureau of Indian Standards (BIS) 2004 Indian Standard specification for drinking water, IS: 10500 .

Bluth G J S and Kump L R 1994 Lithologic and climatologic controls of river chemistry; Geochim. Cosmochim. Acta $582341-2359$

Carbonnel J P and Meybeck M 1975 Quality variations of the Mekong river at Phnom Penh, Combodia and chemical transport in the Mekong basin; J. Hydrol. 27 249-265.

Cerling T E, Pederson B L and Damm K L V 1989 Sodium calcium ion exchange in the weathering of shales: Implications for global weathering budgets; Geology 17 $552-554$.

Chakrapani G J and Subramanian V 1990 Preliminary studies on the geochemistry of the Mahanadi river basin, India; Chem. Geol. 81 241-243.

Dalai T K, Krishnaswami S and Sarin M M 2002 Major ion chemistry in the headwaters of the Yamuna river system: Chemical weathering, its temperature dependence and $\mathrm{CO}_{2}$ consumption in the Himalaya; Geochim. Cosmochim. Acta 66 3397-3416.

Datta S, Thibault Y, Fyfe W S, Powell M A, Har B R, Martin R R and Tripathy S 2002 Occurrence of trona in alkaline soils of the Indo-Gangetic plains of Uttar Pradesh (U.P.), India; Episodes 25 236-239.

Eaton F M 1950 Significance of carbonates in irrigation waters; Soil Sci. 39 123-133.

Fisher S R and Mullican W F 1997 Hydrogeochemical evolution of sodium-sulfate and sodium-chloride ground water beneath the northern Chihuahua Dessert, Trans-Pecos, Texas, USA; Hydrogeol. J. 5 4-16.

Gaillardet J, Dupre B, Louvat P and Allegre C J 1999 Global silicate weathering and $\mathrm{CO}_{2}$ consumption rates deduced from the chemistry of large rivers; Chem. Geol. 159 3-30.

Galy A and France-Lanord C 1999 Weathering processes in the Ganges-Brahmaputra basin and the riverine alkalinity budget; Chem. Geol. 159 31-60.

Garrels R M and Christ C L 1965 Solutions, minerals and equilibria; Harper and Row, New York.

Garrels R M and Mackenzie F T 1971 Gregor's denudation of the continents; Nature 231 382-383.

Garrels R M, Mackenzie F T and Hunt C 1975 Chemical cycle and the global environment; William Kaufman, New York, 260p.

Gibbs R J 1970 Mechanisms controlling world water chemistry; Science 17 1088-1090.

Gibbs R J 1972 Water chemistry of Amazon river; Geochim. Cosmochim. Acta 36 1061-1066.
Gordeev V V and Sidorov I S 1993 Concentration of major elements and their out flow into the Laptev Sea by the Lena river; Mar. Chem. 43 34-45.

Gupta H, Chakrapani G J, Selvaraj K and Kao S J 2011 The fluvial geochemistry, contributions of silicate, carbonate and saline-alkaline components to chemical weathering flux and controlling parameters: Narmada river (Deccan Traps), India; Geochim. Cosmochim. Acta 75 800-824.

Hardie L A and Eugster H P 1970 The evolution of closedbasin brines; Mineral. Soc. Am. Spec Publ. 3 273-290.

Holland H D 1978 The chemistry of the atmosphere and oceans; Willey \& Sons, 351p.

Hren M T, Chamberlain C P, Hilley G E and Bookhagen B 2007 Major ion chemistry of the Yarlung TsangpoBrahmaputra river: Chemical weathering, erosion, and $\mathrm{CO}_{2}$ consumption in the southern Tibetan plateau and eastern syntaxix of the Himalaya; Geochim. Cosmochim. Acta 71 2907-2935.

Hu Ming-Hui, Stallard R F and Edmond J M 1982 Major ion chemistry of the some large Chinese rivers; Nature $298550-553$.

Jha P K, Tiwari J, Singh U K, Kumar M and Subramanian V 2009 Chemical weathering and associated $\mathrm{CO}_{2}$ consumption in the Godavari river basin, India; Chem. Geol. $264364-374$.

Karanth K R 1989 Hydrogeology; Tata McGraw-Hill, New Delhi.

Kelley W P 1951 Alkali soils - Their formation properties and reclamation; Reinhold Publishing Corporation, New York.

Krauskopf K B 1959 The geochemistry of silica in sedimentary environments; In: Silica in sediemnts (ed.) Ireland H A, Soc. Econ. Palaeontol. Mineral. Spec. Publ. 7 4-19.

Krishnaswami S, Trivedi J R, Sarin M M, Ramesh R and Sharma K K 1992 Strontium isotope and rubidium in the Ganga-Brahmaputra river system: Weathering in the Himalaya, fluxes to the Bay of Bengal and contribution to the evolution of oceanic ${ }^{87} \mathrm{Sr} /{ }^{86} \mathrm{Sr}$; Earth Planet. Sci. Lett. $109243-253$.

Krishnaswami S and Singh S K 1998 Silicate and carbonate weathering in the drainage basin of Ganga-GhagraIndus head waters: Contributions to major ion Sr isotope geochemistry; Proc. Indian Acad. Sci. 107 283-291.

Lakshmanan S 1970 Evolution of the Son drainage; Proc. Indian Nat. Sci. Acad. 38(1\&2) 21-31.

Li Siyue, Zhifang Xu, Hao Wang, Jianhua Wang and Quanfa Zhang 2009 Geochemistry of the upper Han River basin, China 3: Anthropogenic inputs and chemical weathering to the dissolved load; Chem. Geol. 264 89-95.

Livingstone D 1963 Chemical composition of rivers and lakes of the world; US Geol. Surv. Prof. Paper; 440G, 64p.

Martin J M and Meybeck M 1979 Elemental mass balance of materials carried by major world rivers; Mar. Chem. 7 $173-206$.

Meybeck M 1976 Total dissolved transport by world major rivers; Hydrol. Sci. Bull. 21 265-289.

Meybeck M 1982 Carbon, nitrogen and phosphorus transport by world rivers; Am. J. Sci. 282 401-450.

Meybeck M 2005 Global occurrence of major elements in rivers; In: Surface and groundwater, weathering, and soils, (ed.) Drever J I, Treatise on Geochemistry, Elsevier, 5 207-223.

Meybeck M, Friedrich G, Thomas R and Chapman D 1996 Rivers; In: Water quality assessment: A guide to use of biota, sediments and water in environmental monitoring, 2nd edn; Chapman and Hall, London, pp. 243-318.

Milliot G 1970 Geology of clays; Springer, BerlinHeildelberg-New York. 
Piper A M 1944 A graphical procedure in the geochemical interpretation of water analysis; Am. Geophys. Union Trans. 25 914-928.

Rai S K, Singh S K and Krishnaswamy S 2010 Chemical weathering in the plain and peninsular sub-basins of the Ganga: Impact on major ion chemistry and elemental fluxes; Geochim. Cosmochim. Acta 74 2340-2355.

Ramakrishnan M and Vaidyanadhan R 2008 Geology of India; Geological Society of India.

Ramanathan A L, Vaithiyanathan P, Subramanian V and Das B K 1994 Nature and transport of solute load in the Cauvery river basin, India; Water Res. 28 15851593.

Ramesh R and Subramanian V 1988 Nature of the dissolved load of the Krishna River basin; J. Hydrol. 103139 155.

Rani N, Sinha R K, Prasad K and Kedia D K 2011 Assessment of temporal variation in water quality of some important rivers in middle Gangetic plains, India; Environ. Monit. Assess. 174 401-415.

Rao K L 1975 India's water wealth; Orient Longman, Delhi.

Ray J S, Veizer J and Davis W J 2003 C, O, Sr and $\mathrm{Pb}$ isotope systematics of carbonate sequences of the Vindhyan Supergroup, India: Age, diagenesis, correlations and implications for global events; Precamb. Res. 121 103-140.

Reeder S W, Hitchon B and Levinson A A 1972 Hydrogeochemistry of the surface waters of the Mackenzie drainage basin, Canada. 1. Factors controlling inorganic composition; Geochim. Cosmochim. Acta 36 825865.

Rengarajan R, Singh S K, Sarin M M and Krishnaswami S 2009 Strontium isotopes and major ion chemistry in the Chambal River system, India: Implications to silicate erosion rates of the Ganga; Chem. Geol. 260 87-101.

Richards L A 1954 Diagnosis and improvement of saline and alkali soils; US Department of Agricultural Hand Book, No. 60160.

Sarin M M and Krishnaswami S 1984 Major ion chemistry of the Ganga-Brahmaputra river systems, India; Nature $312538-541$.

Sarin M M, Krishnaswamy S, Dilli K, Somayajulu B L K and Moore W S 1989 Major ion chemistry of the GangaBrahmaputra river system: Weathering processes and fluxes to the Bay of Bengal; Geochim. Cosmochim. Acta 53 997-1009.

Sharma S K and Subramanian V 2008 Hydrochemistry of the Narmada and Tapti River, India; Hydrol. Process. 22 3444-3455.
Singh A K and Hasnain S I 1999 Environmental geochemistry of Damodar river basin - east coast of India; Environ. Geol. 37 124-136.

Singh S K, Sarin M M and France-Lanord 2005 Chemical erosion in the eastern Himalaya: Major ion composition of the Brahmaputra and $\delta^{13} \mathrm{C}$ of dissolved inorganic carbon; Geochim. Cosmochim. Acta $693573-3588$.

Stallard R F and Edmond J M 1983 Geochemistry of the Amazon. The influence of the geology and weathering environment on the dissolved load; J. Geophys. Res. $\mathbf{8 8}$ 9671-9688.

Stumm W and Morgan J J 1981 Aquatic chemistry; Wiley Intersci., New York.

Subba Rao N and John Devadas D 2003 Fluoride incidence in ground water in an area of peninsular India; Environ. Geol. 45 243-253.

Subramanian V 1979 Chemical and suspended sediment characteristics of rivers of India; J. Hydrol. 44 37-55.

Subramanian V 1983 Factors controlling the chemical composition of rivers of India; In: Proceeding of Hamburg Symposium; IAHS Publ. 141 145-151.

Subramanian V 1984 Erosion and sediment transport in the Ganges river basin (India); J. Hydrol. 69 173-182.

Subramanian V, Biksham G and Ramesh R 1987 Environmental geology of peninsular river basins of India; J. Geol. Soc. India 30 393-401.

Taylor S R and McLennan S M 1985 The continental crust: Its composition and evolution; Blackwell, Oxford.

Tipper E T, Biclkle M J, Galy A, West A J, Pomies's C and Chapman H J 2006 The short term climatic sensitivity of carbonate and silicate weathering fluxes: Insight from seasonal variation in river chemistry; Geochim. Cosmochim. Acta 70 2737-2754.

WHO 2004 Guidelines for drinking water quality; World Health Organization, Geneva.

Wilcox L V 1955 Classification and use of irrigation waters; USDA Circ 969, Washington, DC.

Xu Zhifang, Shi Chao, Tang Yang and Han Hongyin 2011 Chemical and strontium isotopic compositions of the Hanjiang Basin Rivers in China: Anthropogenic impacts and chemical weathering; Aquat. Geochem. 17 243-264.

Yadav S K and Chakrapani G J 2011 Geochemistry, dissolved elemental flux rates, and dissolution kinetics of lithologies of Alaknanda and Bhagirathi rivers in Himalayas, India; Environ. Earth Sci. 62 593-610.

Zhang J, Huang W W, Letolle R and Jusserand C 1995 Major element chemistry of the Huanghe Yellow river China - weathering processes and chemical fluxes; J. Hydrol. 168 173-203. 